\title{
Cyclodextrins, Natural Compounds, and Plant Bioactives-A Nutritional Perspective
}

\author{
Svenja Wüpper *, Kai Lüersen and Gerald Rimbach
}

Citation: Wüpper, S.; Lüersen, K.; Rimbach, G. Cyclodextrins, Natural Compounds, and Plant Bioactives-A Nutritional Perspective. Biomolecules 2021, 11, 401. https://doi.org/ 10.3390/biom 11030401

Academic Editor: Anika Wagner

Received: 10 February 2021

Accepted: 4 March 2021

Published: 9 March 2021

Publisher's Note: MDPI stays neutral with regard to jurisdictional claims in published maps and institutional affiliations.

Copyright: (c) 2021 by the authors. Licensee MDPI, Basel, Switzerland. This article is an open access article distributed under the terms and conditions of the Creative Commons Attribution (CC BY) license (https:/ / creativecommons.org/licenses/by/ $4.0 /)$.
Institute of Human Nutrition and Food Science, University of Kiel, Hermann-Rodewald-Strasse 6, 24118 Kiel, Germany; luersen@foodsci.uni-kiel.de (K.L.); rimbach@foodsci.uni-kiel.de (G.R.)

* Correspondence: wuepper@foodsci.uni-kiel.de; Tel.: +49-431-880-5334

\begin{abstract}
Cyclodextrins (CDs) are a group of cyclic oligosaccharides produced from starch or starch derivatives. They contain six $(\alpha C D)$, seven $(\beta C D)$, eight $(\gamma C D)$, or more glucopyranose monomers linked via $\alpha-1,4$-glycosidic bonds. CDs have a truncated cone shape with a hydrophilic outer wall and a less hydrophilic inner wall, the latter forming a more apolar internal cavity. Because of this special architecture, CDs are soluble in water and can simultaneously host lipophilic guest molecules. The major advantage of inclusion into CDs is increased aqueous solubility of such lipophilic substances. Accordingly, we present studies where the complexation of natural compounds such as propolis and dietary plant bioactives (e.g., tocotrienol, pentacyclic triterpenoids, curcumin) with $\gamma$ CD resulted in improved stability, bioavailability, and bioactivity in various laboratory model organisms and in humans. We also address safety aspects that may arise from increased bioavailability of plant extracts or natural compounds owing to CD complexation. When orally administered, $\alpha$ - and $\beta C D-$ which are inert to intestinal digestion-are fermented by the human intestinal flora, while $\gamma \mathrm{CD}$ is almost completely degraded to glucose units by $\alpha$-amylase. Hence, recent reports indicate that empty $\gamma \mathrm{CD}$ supplementation exhibits metabolic activity on its own, which may provide opportunities for new applications.
\end{abstract}

Keywords: cyclodextrins; gamma-cyclodextrin; complex; ursolic acid; oleanolic acid; betulinic acid; propolis; tocotrienol; curcumin

\section{Introduction}

Cyclodextrins (CDs), also known as cyclomaltoses, cycloamyloses, and Schardinger dextrins, are a group of cyclic oligosaccharides that are produced from starch or starch derivatives by the bacterial enzyme cyclodextrin glycosyltransferase (CGTase) [1,2]. CDs contain six or more glucopyranose monomers linked via $\alpha-1,4$-glycosidic bonds. The most prominent members of the CD family are $\alpha$ - (six glucopyranose units), $\beta$ - (seven glucopyranose units), and $\gamma \mathrm{CD}$ (eight glucopyranose units, Figure 1) [1]. Through the specific steric arrangement of their glucose units, CDs are soluble in water and can function as important complexation agents for a broad range of more lipophilic molecules, including natural compounds and plant bioactives, with increasing use in industrial and research applications [1,3]. The major advantage of the inclusion of lipophilic substances into CDs is increased aqueous solubility with enhanced stability and bioavailability of these guest molecules. In addition, CDs can be used to prevent drug-drug and drug-excipient interactions, convert liquid drugs into microcrystalline powder, and reduce gastrointestinal drug irritation [4].

This review aims to provide a short historical overview as well as a summary of the synthesis, properties, pharmacokinetics, and safety of CDs. Furthermore, the differences among the three main $\mathrm{CD}$ types are addressed with respect to their complex formation and route of administration. The present state of knowledge regarding the stability, bioavailability, and bioactivity of $\gamma \mathrm{CD}$ complexes with selected natural compounds and dietary plant bioactives is described. Finally, the biological activity of empty $\gamma \mathrm{CD}$ is also reviewed. 


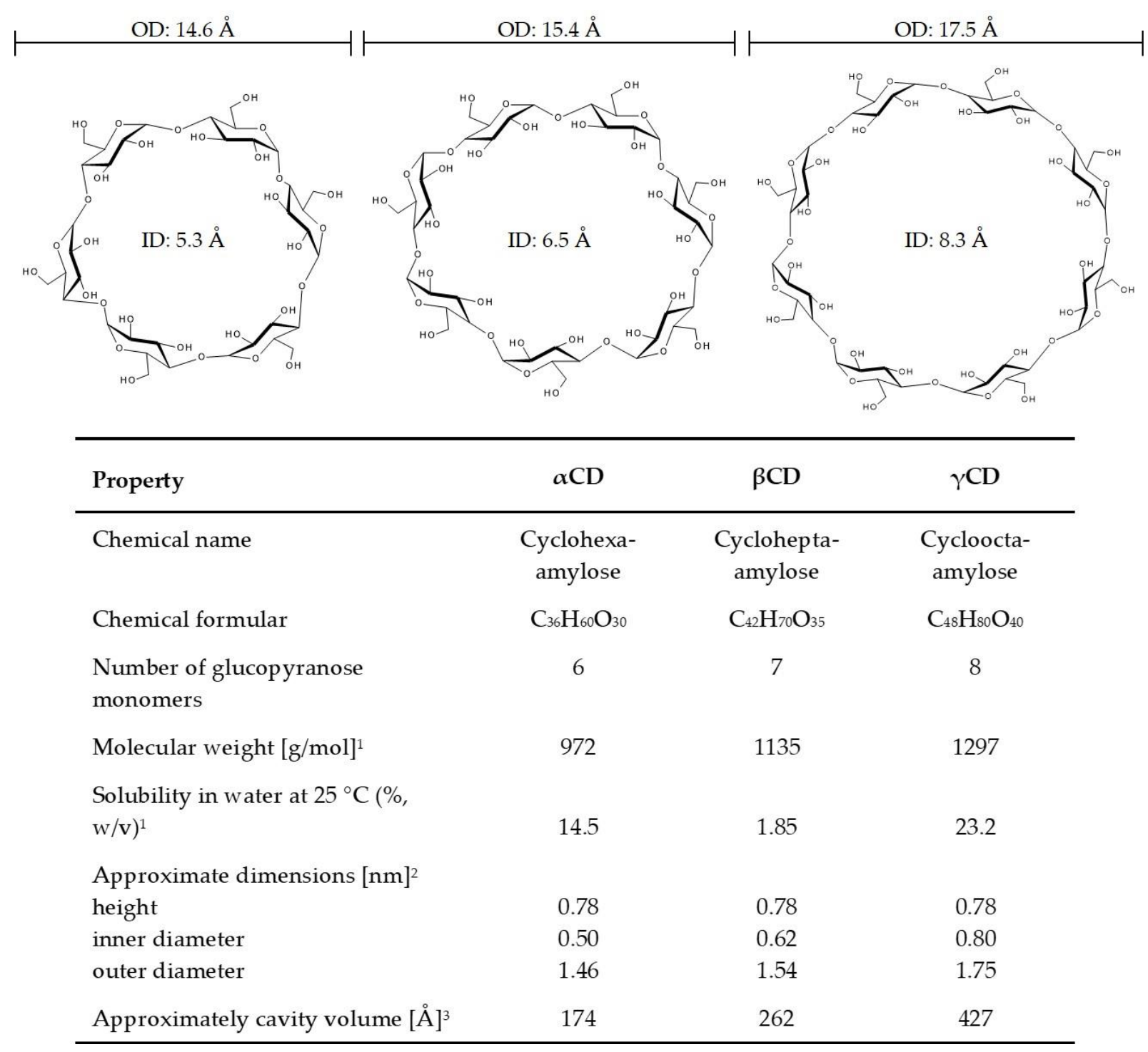

Figure 1. Chemical structures and physicochemical properties of the three main cyclodextrins $\alpha$-, $\beta$-, and $\gamma$-cyclodextrin (from left to right $\alpha \mathrm{CD}, \beta \mathrm{CD}$, and $\gamma \mathrm{CD}$ ). ID: Inner diameter; OD: Outer diameter. ${ }^{1}$ From [2]. ${ }^{2}$ From [5]. ${ }^{3}$ From [1].

\section{History of Cyclodextrins}

$\alpha$ - and $\beta C D$ were discovered in 1891 by the French pharmacist and chemist Antoine Villiers as digestion products of potato starch obtained by using the bacterium Bacillus amylobacter (Figure 2). Villiers named the novel carbohydrates "cellulosines" $\alpha$ - and $\beta$-dextrin and described them as crystalline and slightly sweet [6]. At the beginning of the 20th century, the Austrian microbiologist Franz Schardinger, later known as the "founding father" of CD chemistry, isolated CDs, which he termed "crystalline dextrins", from several sources of starch following digestion by Bacillus macerans. Notably, B. macerans is still the most commonly used bacterial species for the production of CGTase to form CDs $[2,6,7]$. In the 1940s, the German chemist Freudenberg and his coworkers discovered $\gamma \mathrm{CD}$ and subsequently solved the cyclic oligosaccharide structure of CD molecules. After discovering the feasibility of preparing CD-inclusion complexes, Freudenberg, Cramer, and Plieninger obtained the first CD-related patent in 1953, which marks the starting point for the application of CDs in drug formulations [8], so that they were no longer just part of academic research, but also part of industrial applications. In 1957, the American chemist and biochemist Dexter French reported on two larger CDs, $\delta$-dextrin and $\varepsilon$-dextrin, with 9 and 10 glucose monomers, respectively $[9,10]$. However, compared to those of the 
smaller CDs, the physicochemical properties of these larger CDs were found to be less suitable for complex formation [8]. In 1980, Saenger found that the amylase CGTase is responsible for the conversion of starch or starch derivatives into $C D$ s via a cyclization reaction. Most importantly, this discovery enabled the mass production of CDs [2,7].

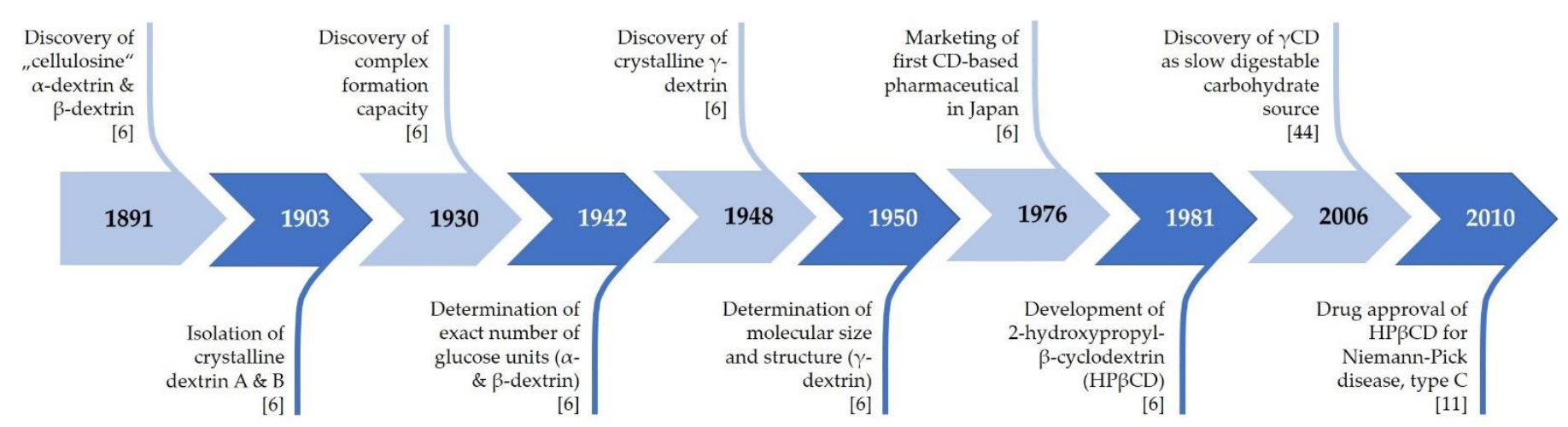

Figure 2. Milestones of cyclodextrin research history. $C D$, cyclodextrin; $\gamma C D$, gamma-cyclodextrin; $H P \beta C D, 2-$ hydroxypropyl-beta-cyclodextrin.

Roughly, the history of CDs can be classified into two main research fields. On the one hand, a main focus is the complexation property of CDs and their role as host molecules to improve the properties of guest molecules. As mentioned above, this traditional research area started in the 1950s, has become well established and is still continuing. With the turn of the new millennium, a new branch of $\mathrm{CD}$ research came to the fore, after the realization that empty CDs exhibit bioactivity on their own and have potential health benefits. Hence, $\mathrm{CD}$ molecules per se have received attention in research, and this topic is increasingly recognized as important [6,11].

\section{Synthesis of Cyclodextrins}

The amylase CGTase (1,4- $\alpha$-D-glucan 4- $\alpha$-D-(1,4- $\alpha$-D-glucano)-transferase) is a unique extracellular enzyme capable of catalyzing the cyclization reaction to form nonreducing CDs from starch, amylose, and other polysaccharides. In addition, CGTase catalyzes two other main transglycosylation reactions (coupling, disproportionation) and exhibits a weak hydrolyzing activity. A common feature of the reactions catalyzed by CGTase is the cleavage of an $\alpha$-glycosidic bond. However, coupling is the reverse reaction of cyclization, where $\mathrm{CD}$ is the substrate and the generated linear malto-oligosaccharide is transferred to an acceptor substrate. During disproportionation, a linear malto-oligosaccharide is cleaved, and the shorter product is transferred to an acceptor substrate $[1,12,13]$. The $\gamma$-cyclization reaction starts with the bond cleavage of polysaccharides. As a result, a covalent intermediate is formed. The two ends of the linear chain of the intermediate will be joined to form a cyclic oligosaccharide (Figure 3) [1,5]. The most crucial catalytic amino acid residues implicated in bond cleavage are Asp229 and Glu257 [1]. During bond formation, an $\alpha-1,4$-glycosidic bond is closed again [1]. 


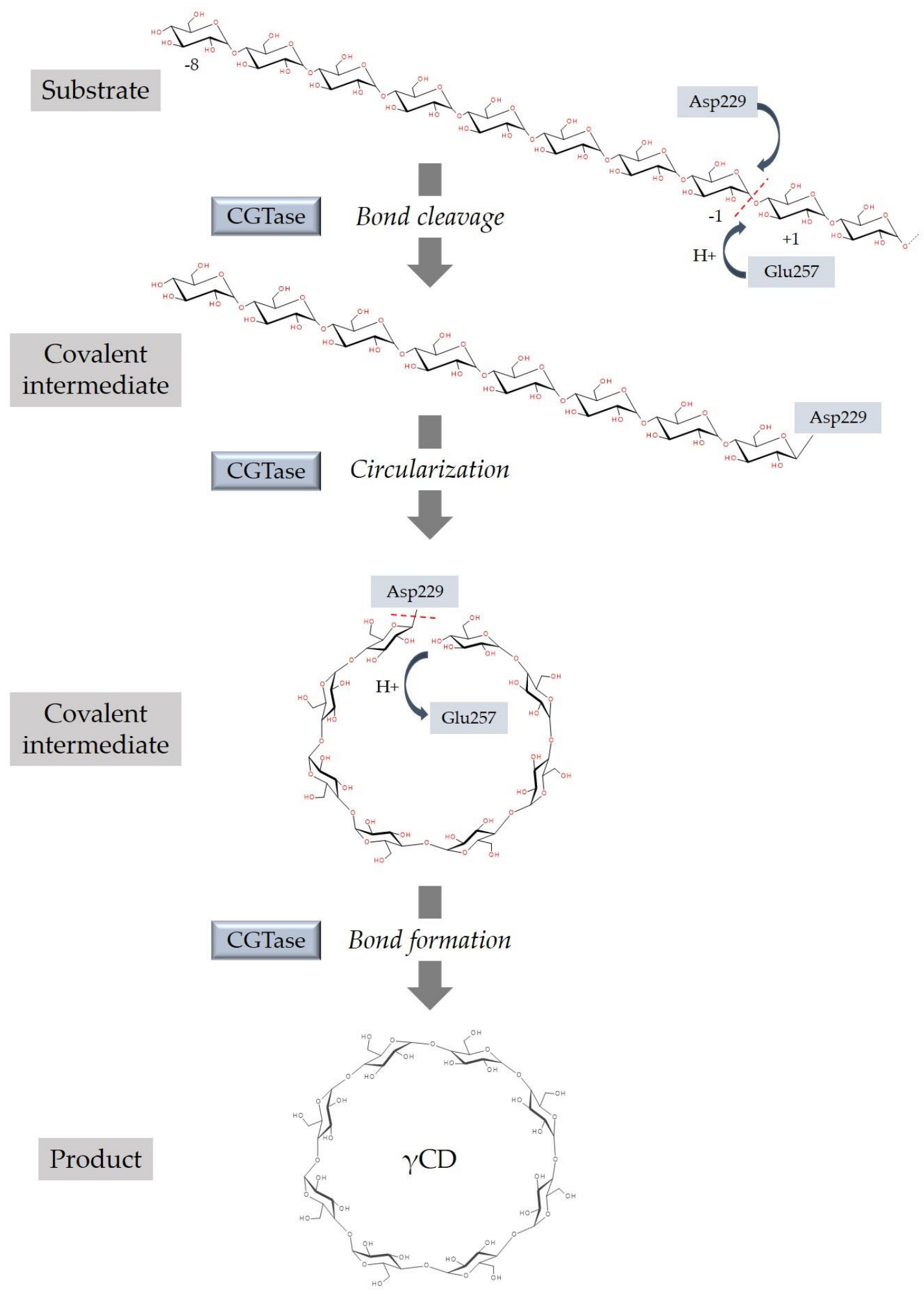

Figure 3. Schematic illustration of $\gamma$-cyclodextrin synthesis. The catalyzing enzyme CGTase (1,4- $\alpha$-D-glucan 4- $\alpha$-D-(1,4$\alpha$-D-glucano)-transferase) first cleaves an $\alpha$-glycosidic bond in starch by a nucleophilic attack of the amino acid residue Asp229. The generated linear malto-oligosaccharide intermediate is covalently $\beta$-1,4-linked to Asp229. In a second step, the oligosaccharide-enzyme intermediate is cleaved under the formation of a cyclic oligosaccharide molecule by closing an $\alpha-1,4$-glycosidic bond between the two outer glucose units. In the cleavage step, the amino acid residue Glu257 functions as a proton donor for the subsite +1 glucose unit of the leaving starch molecule and, subsequently, in the cycling step as a proton acceptor. Adapted from [1,14]. $\gamma \mathrm{CD}$, gamma-cyclodextrin. 
CGTases are found in many bacteria, but have also been identified in archaea. Mainly for historical reasons, CGTases from Bacillus species are the most extensively studied enzymes [13]. All known CGTases convert starch to a mixture of $\alpha-, \beta-$, and $\gamma$ CDs [12]. Depending on the enzyme source, the product mixtures differ in their relative amounts of $\alpha-, \beta-$, and $\gamma$-CDs. Hence, CGTases can be further classified according to their major CD products [5]. To obtain individual $\alpha$ - and $\gamma$ CDs from the produced mixture, a costly and time-consuming separation is needed [1]. Therefore, CGTases producing a high amount of a single-type CD are often used and, in addition, have been genetically improved [1,13]. For example, Bacillus thuringiensis strain GU-2 was isolated from soil as a specific $\gamma$ CDproducing strain with a purity of $>95 \%$ when starch was used as the substrate. The optimum conditions were reported to be $\mathrm{pH} 8.5$ and $37{ }^{\circ} \mathrm{C}$ [15]. Compared to $\alpha$ - and $\gamma \mathrm{CD}$, the separation and purification of $\beta C D$ is relatively easy, and therefore rather inexpensive due to its low solubility in water [13].

\section{Properties of Cyclodextrins}

The CDs of the so-called "first generation" or "parent cyclodextrins" are $\alpha-, \beta-$, and $\gamma \mathrm{CD}$. These polysaccharides consist of six, seven, or eight glucopyranose monomers linked via $\alpha$-1,4-glycosidic bonds (Figure 1) [2], forming a truncated cone shape with a central axial cavity [16]. Main properties of the three CDs are listed in Figure 1.

The CD molecules have a hydrophilic outer wall because of the free hydroxyl groups on the outside of the molecules and a less hydrophilic or hydrophobic inner wall imparted by the ether oxygen atoms in the glycosidic hemiacetals and the carbon-hydrogen atoms [11]. Accordingly, CDs are soluble in water, yet can form complexes with many hydrophobic guest molecules [2] through the slightly apolar internal cavities. Binding studies by Heredia et al. [17] and Kajtár et al. [18] indicated that the internal polarity of both $\beta$ - and $\gamma \mathrm{CD}$ are comparable with alcoholic solutions. Moreover, as shown by Street and Acree [19], the estimated dielectric constants for the internal cavities of $\beta$ - and $\gamma \mathrm{CD}$ are only slightly different. Since the depth of the cavities is similar in all parent CDs, their inner diameter, which increases with the number of glucose subunits and determines the cavity size (Figure 1), represents the main limiting factor for the ability to host organic molecules. In good accordance to the increasing cavity size, $\alpha \mathrm{CD}$ can harbor up to 6.6 molecules water/molecule, $\beta C D$ up to 11 molecules water/molecule, and $\gamma \mathrm{CD}$ up to 17 molecules water/molecule [16].

In addition to the central cavity, an essential feature of CDs is the location of the hydroxyl groups [20]. There are secondary hydroxyl groups at the broadest end of the toroid bonded to glucose units at C2 and C3 atoms (Figure 4a). At the opposite end, primary hydroxyl groups are attached to glucose at C6 atoms. These hydroxymethyl groups define the narrowest end of the CD molecule with the smallest cavity diameter. This is based on the property of free rotation from hydroxymethyl groups [21]. Advantages from complexation with CDs are higher water solubility, stability, diffusibility, and bioavailability of guest molecules [22], and masking of ill smell and taste of guest molecules [3]. For example, a propolis- $\gamma$ CD complex possesses a less pungent taste, is water soluble, and stable to heat compared to propolis [23]. To further enhance the water solubility as well as the ability to form inclusion complexes with parent CDs, changes in their free hydroxyl groups have been made [24], resulting in CD derivatives such as 2-hydroxypropyl- $\gamma C D(H P \gamma C D)$. 


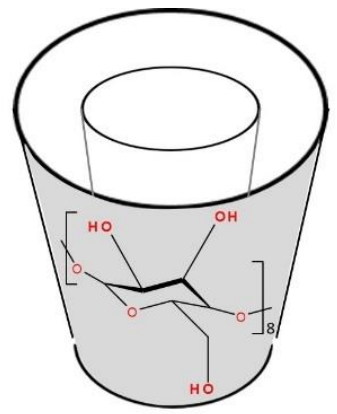

(a)

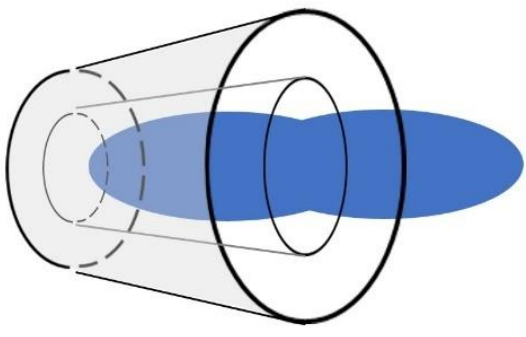

(b)<smiles>O=C(/C=C/c1ccc(O)c(O)c1)OCCc1ccccc1</smiles>

CAPE

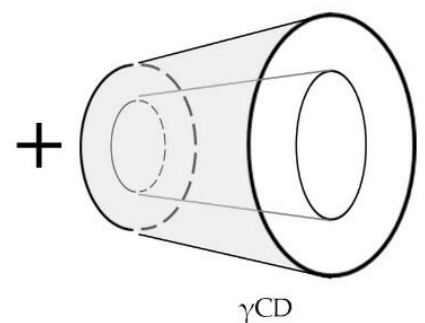

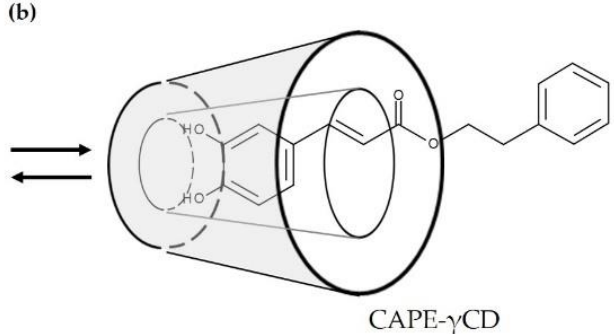

CAPE- $\gamma$ CD

Figure 4. Conical shape of cyclodextrins and complex formation. (a) The secondary hydroxyl groups of the glucose molecules are located at the broadest end of the toroid, while the primary hydroxyl groups constitute the narrowest end of the $\gamma$-cyclodextrin toroid, here shown representatively for cyclodextrins. (b) Schematic illustration of cyclodextrin and guest molecule forming a complex in a 1:1 molar ratio. Adapted from [25]. (c) Chemical structure of caffeic acid phenethyl ester (CAPE) and illustration of complex formation of CAPE and $\gamma$-cyclodextrin. Adapted from [23,26]. CAPE, caffeic acid phenethyl ester; CAPE- $\gamma$-cyclodextrin (CAPE- $\gamma \mathrm{CD}) ; \gamma \mathrm{CD}, \gamma$-cyclodextrin.

The capacity to form inclusion complexes with lipophilic substances resulted in a broad range of applications for CDs, especially in analytical chemistry, agriculture, the pharmaceutical field, food, and hygienic articles [3]. When describing CDs as tasteless, odorless, nondigestible, noncaloric, and noncariogenic for humans [27], one should keep in mind that the three $\mathrm{CD}$ molecules have somewhat different properties. The native CDs are fermented by the human intestinal flora [21]. However, $\gamma \mathrm{CD}$ differs from the other two parent $\mathrm{CDs}$ in that it is degraded by amylases to form glucose and other low molecular weight sugar molecules [5,22], which is important for oral administration and thereby calls into question the nondigestible and noncaloric specifications. In turn, undigested $\gamma C D$ is available for fermentation. The metabolic fate of $\alpha$ - and $\beta C D$ is quite similar to that of other nondigestible but fermentable carbohydrates [27], thereby providing energy for colonic epithelial cells, mainly in the form of butyrate [28]. Furthermore, $\gamma C D$ shows the highest water solubility $[5,22]$. In addition, $\gamma C D$ has a great advantage over $\alpha C D$ and $\beta C D$ in trapping larger molecules because it has the largest internal cavity volume (Figure 1) [1].

\section{Absorption, Distribution, Metabolism, and Excretion of Cyclodextrins}

Based on pharmacokinetic studies of CDs, orally administered CDs have low bioavailability, and systemically absorbed CDs disappear rapidly from the body, mostly unmetabolized in urine [29-32].

It has been shown that orally administered $\alpha \mathrm{CD}$ at a dose of $200 \mathrm{mg} / \mathrm{kg}$ body weight (BW) in rats exhibited an absorption rate of $1 \%$. Excretion of intact $\alpha \mathrm{CD}$ after oral gavage was carried out via the kidneys. In this context, it is interesting that no intact $\alpha \mathrm{CD}$ was found in the feces, which indicates that $\alpha \mathrm{CD}$ is completely fermented by the intestinal microbiota, such as resistant starch or other types of fermentable dietary fiber [30]. Intravenous administration of 14C-labelled $\alpha \mathrm{CD}$ to Wistar rats indicated half-lives of 21 and $26 \mathrm{~min}$ in blood in male and female rats, respectively. Furthermore, it has been shown that $\alpha \mathrm{CD}$ is excreted rapidly in urine, and only approximately $1.9 \%$ of systemic $\alpha \mathrm{CD}$ is eliminated with bile or saliva [30]. 
Male Wistar rats employed by Kubota et al. (1996) received $\beta C D$ orally at a dose of $500 \mathrm{mg} / \mathrm{kg}$. Here, $\beta C D$ reached the maximum plasma concentration within $40 \mathrm{~min}$ with an absorption rate of $0.6 \%$ [29]. Intravenously administered $\beta C D(25-100 \mathrm{mg} / \mathrm{kg})$ exhibited a half-life of 22-26 min in blood. The urinary excretion of intact $\beta C D$ was approximately $90 \%$ within $10 \mathrm{~h}$ [29] or $24 \mathrm{~h}$ [32] after intravenous administration. According to these findings, $\beta C D$ is essentially eliminated via urine without undergoing relevant metabolism in rats [29,32].

The enzyme $\beta$-amylase hydrolyses starch from the nonreducing end. Although $\gamma \mathrm{CD}$ is resistant to degradation by $\beta$-amylase, it is a substrate of salivary and pancreatic $\alpha$-amylase, whereas $\alpha$ - and $\beta C D$ are not. The $\alpha$-amylase hydrolyses $\alpha$-bonds from large polysaccharides such as starch. $\gamma \mathrm{CD}$ is almost completely degraded to malto-triose, maltose, and glucose, similar to the digestion of starch and linear dextrins $[5,33,34]$. The degradation of $\gamma \mathrm{CD}$ through $\alpha$-amylase starts with a ring-opening reaction, which is the slowest step of the degradation process of $\gamma \mathrm{CD}$. Linear malto-octaose is the result of this ring-opening reaction, and can be further degraded by amylases [34]. It has been assumed that the higher number of glucose molecules in $\gamma \mathrm{CD}$ than in $\alpha$ - and $\beta C D$ could be why $\gamma \mathrm{CD}$ can be degraded by $\alpha$-amylase. The eight glucose monomers of $\gamma \mathrm{CD}$ and the higher flexibility in its circular structure result in higher susceptibility to the opening reaction of amylases [34]. Glucose is readily absorbed from the gastrointestinal tract, whereas the absorption of intact $\gamma \mathrm{CD}$ has been reported to be very low (0.02\%) [31]. Moreover, the formation of inclusion complexes with $\gamma \mathrm{CD}$ decreased hydrolysis by $\alpha$-amylase [35]. Intravenously administered $14 \mathrm{C}-\gamma \mathrm{CD}$ indicated a half-life of 15-20 min in blood. Excretion kinetics showed that approximately $90 \%$ of $\gamma \mathrm{CD}$ was excreted in urine within $24 \mathrm{~h}$ [31].

\section{Safety of Cyclodextrins}

A high parenteral dose of $\beta C D(200 \mathrm{mg} / \mathrm{kg})$ in rats led to a decreased elimination rate, suggesting that this high dose may be nephrotoxic [32]. The renal toxicity of high parenteral doses of $\alpha \mathrm{CD}$ [36] and $\beta C D$, respectively, has been reported elsewhere [36,37]. The occurrence of crystals in renal tissue might explain the nephrotoxicity [36,37]. However, a dietary level of $\alpha \mathrm{CD}$ up to $20 \%$ did not reveal adverse effects or signs of toxicity in studies in rats and beagle dogs [38,39]. In healthy humans, treatment with $6 \mathrm{~g} \alpha \mathrm{CD}$ per day for 12-14 weeks in a randomized, double-blind clinical trial was well tolerated. Only mild gastrointestinal symptoms occurred and may be side effects related to oral $\alpha C D$ administration [40]. The toxicity of $\beta C D$ was studied in Sprague-Dawley rats and beagle dogs receiving orally administered $\beta C D$ for up to 52 weeks. The nontoxic effect level in rats was 654 or $864 \mathrm{mg} / \mathrm{kg} /$ day for males or females, respectively, and 1831 or $1967 \mathrm{mg} / \mathrm{kg} /$ day for male dogs or female dogs, respectively [41].

No signs of toxicity from $\gamma \mathrm{CD}$ have been shown in acute toxicity studies in mice and rats after oral, subcutaneous, intravenous, and intraperitoneal administration [5]. A dietary level of up to $20 \% \gamma \mathrm{CD}$ has been shown to be well tolerated without toxic side effects on the basis of studies in beagle dogs and Wister rats [5,42]. A dietary level of up to $20 \% \gamma \mathrm{CD}$ in pregnant female rats did not reveal any fetotoxic, embryotoxic, or teratogenic effects [43]. The oral toxicity of up to $20 \% \gamma \mathrm{CD}$ in the diet was examined in beagle dogs over a 13-week period. The only treatment-related observed effects were transient diarrhea and cecal enlargement. Both side effects are well-known physiological responses to high doses of orally administered carbohydrates [42]. In humans, a single oral dose of $50 \mathrm{~g}$ of carbohydrate from $\gamma \mathrm{CD}$ or maltodextrin was administered in a doublemasked, randomized, crossover study with 32 healthy adult subjects. The treatments were both well tolerated [44].

Overall, all three parent CDs are "generally recognized as safe" (GRAS) by the U.S. FDA for use as a food additive [45-47]. Furthermore, $\beta C D$ is approved in Europe as a food additive (E459) with an acceptable daily intake (ADI) of $5 \mathrm{mg} / \mathrm{kg}$ BW per day [48]. However, the European Medicines Agency (EMA) recommends against the parenteral use 
of $\alpha \mathrm{CD}$ and $\beta C D$ due to their hepatotoxicity, although there has been one intravenous product containing $\alpha \mathrm{CD}$ on the market in Japan [49].

\section{Cyclodextrin Inclusion Complexes}

During complexation, guest molecules and CD molecules come into contact with each other to unite and form a complex [50]. In most cases, one guest molecule forms a complex with one CD molecule, resulting in a 1:1 type of CD complex (Figure $4 b)[4,26,51]$.

In aqueous solutions, the internal cavity of CDs is occupied by water molecules. These water molecules can be substituted by less polar guest molecules. The driving force is the polar-apolar interaction between water and $C D$, which results in an energetically unfavored environment. Complex formation takes place through substitution with an appropriate guest molecule or, more commonly, some lipophilic moiety of the molecule, which is less polar than water molecules $[4,8]$. This process reduces the total energy of the system and causes a change in enthalpy, resulting in enhanced stability of the complex [21], while no covalent bonds are formed or broken [4]. Therefore, water is almost necessary in the formation of complexes [50]. During the complexation process, negative values of free energy changes by the Gibbs equation have been shown for ursolic acid (UA) and oleanolic acid (OA) with $\beta C D$ and $\gamma C D$, respectively, indicating that complexation was a spontaneous process $[24,26]$.

Various methods have been applied to prepare CD complexes: The solution method, coprecipitation method, neutralization method, slurry method, kneading method, and grinding method [4,50]. Factors such as temperature, amount of water, mixing time, and drying conditions have to be adapted for each guest molecule and CD complex [50]. For example, the triterpenoids UA, OA, betulinic acid (BA), and betulin (Bet) formed complexes with $C D$ when using the kneading method [52-54]. Both BA and Bet were encapsulated in a $\gamma C D$ derivative with a molar ratio of 1:1. An equal quantity of ethanol and water (1:1) was used as the solvent mixture. All materials were continuously kneaded together for several minutes until the majority of the solvent mixture had been evaporated. The resulting mixture was dried at room temperature for $24 \mathrm{~h}$ and then in an oven at $105^{\circ} \mathrm{C}$ for $7 \mathrm{~h}$. Then, the final product was pulverized and sieved [52,54].

The host-guest interaction of OA and UA with $\beta C D$ was studied by Huang et al. [26]. They found that the kneading method resulted in products with higher drug loading, but limited improvement in solubility. Therefore, the authors chose the stirring method because the stirred products showed better inclusion and were more easily obtained [26]. Furthermore, it has been shown that both the stability constant $(\mathrm{K})$ and the complexation efficiency (CE) of UA were higher than those of OA. Because OA and UA have a very similar chemical structure except for the location of one methyl group on ring E (Figure 5), it has been assumed that ring E of both triterpenoids was encapsulated in the CD cavity [26]. For further information about the mechanism behind complexation, the hydrogen bonding parameters were analyzed. Two intermolecular hydrogen bonds were revealed between $\mathrm{OA}$ or $\mathrm{UA}$ and $\beta C D$. The hydrogen bonds were formed between the $\mathrm{H}$ atom on the carbonyl group of $\mathrm{UA}(\mathrm{OA})$ and the $\mathrm{O}$ atom in $\beta C D$ and between the $\mathrm{O}$ atom in the carbonyl group of $\mathrm{UA}(\mathrm{OA})$ and the $\mathrm{H}$ atom bonding to the $\mathrm{C}$ atom in $\beta \mathrm{CD}[26,26]$. The most stable complex structure was reported to have the carboxyl group oriented to the center of the CD cavity $[24,26]$.

Another studied complex is caffeic acid phenethyl ester (CAPE) $-\gamma C D$. The structure of CAPE, a key anticancer phenolic compound in New Zealand propolis, as well as the complex structure of CAPE- $\gamma C D$, is shown Figure 4c [23]. It is suggested that the caffeic acid moiety is encapsulated in the CD cavity. 

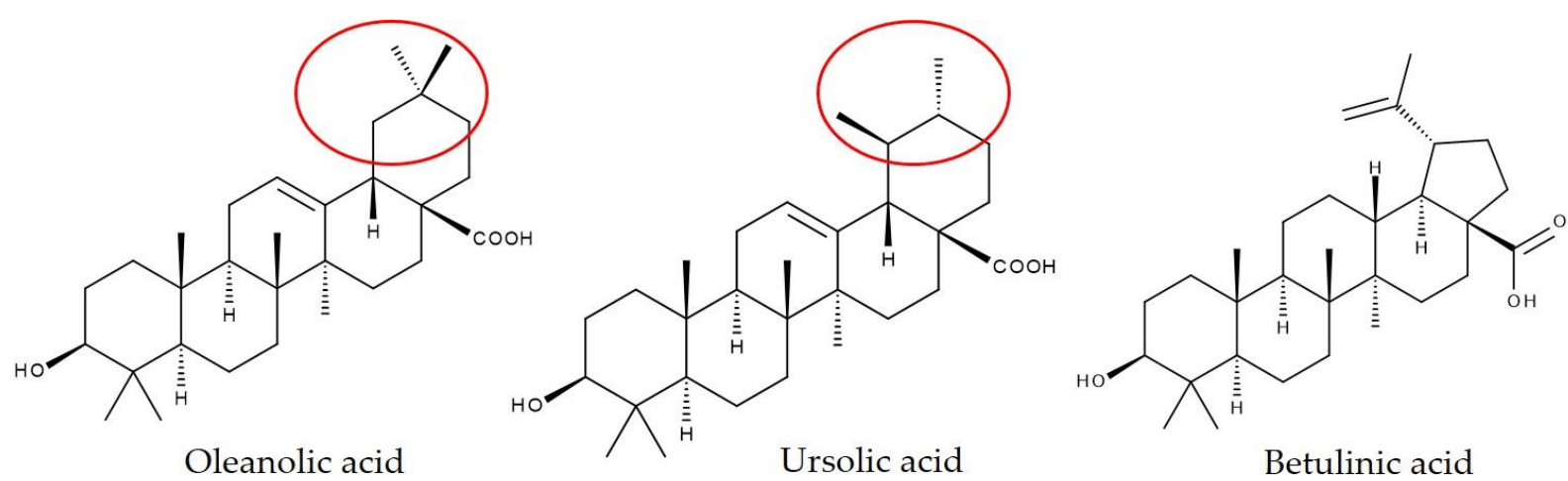<smiles>CC(C)=CCC/C(C)=C/CC/C(C)=C/CC[C@]1(C)CCc2cc(O)c(C)c(C)c2O1</smiles><smiles>COc1cc(/C=C/C(=O)CC(=O)/C=C/c2ccc(O)c(O)c2)ccc1O</smiles>

Curcumin

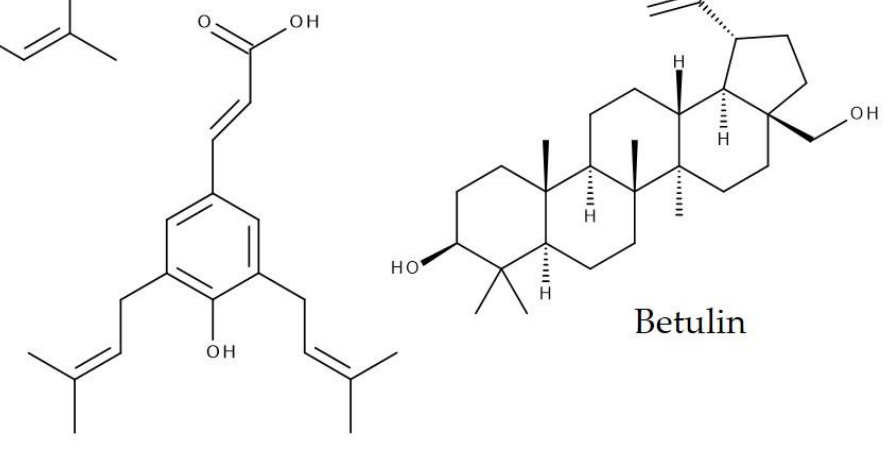

Artepillin C

Figure 5. Chemical structures of oleanolic acid, ursolic acid, betulinic acid, $\gamma$-tocotrienol, curcumin, artepillin C, and betulin. Oleanolic acid and ursolic acid differ in the location of one methyl group on ring E [26], highlighted by the red circles.

\section{Application of Cyclodextrins}

In 2017, approximately 70\% of global CD production consisted of $\beta C D$, while the shares of $\alpha \mathrm{CD}$ and $\gamma \mathrm{CD}$ were approximately $15 \%$ and $5 \%$, respectively. However, due to its favorable toxicological profile, $\gamma \mathrm{CD}$, which was initially less produced, is becoming increasingly attractive as a pharmaceutical excipient [5]. In Japan, native CDs are regarded as natural products, resulting in usage without many restrictions both in medicines and in foods [11]. CDs have been used in food and pharmaceutical products for many years, largely to form inclusion complexes with problematic drugs to enhance their solubility [55]. In addition, previous studies have shown that CDs are useful as an antibacterial food packaging material when forming inclusion complexes with natural antimicrobial agents such as thymol and carvacrol [56-65]. This embedment of an antibacterial agent into food packaging material is one strategy to inhibit bacterial growth. Mostly, $\beta C D$ was successfully employed as a host molecule. However, Aytac et al. [56] tested thymol- $\gamma C D$ inclusion complex-encapsulated electrospun zein nanofibrous webs (zein-THY- $\gamma$ CD-NF) as a potential food packaging material for meat samples. The electrospun nanofibers were prepared from a solution of THY- $\gamma$ CD complex-incorporated zein. The antibacterial activity of zein-THY- $\gamma$ CD-NF against Escherichia coli and Staphylococcus aureus was higher than that of zein-THY-NF without $\gamma C D$. Therefore, the webs are of interest for application as antibacterial food packaging materials [56].

As reported by Fenyvesi, Vikmon, and Szente [27], the food application of CDs started in the 1970s. In particular, $\gamma C D$ has received much attention in oral bioavailability experiments and is regarded as a promising nutrition delivery system [22]. An overview of bioavailability and bioactivity of inclusion complexes of tocotrienols, pentacyclic triterpenoids, propolis and curcumin with $\gamma$ CD is given in Table 1. $\gamma$ CD can stabilize diverse food factors, such as flavors, sensitive colors, fat-soluble vitamins, polyunsaturated fatty 
acids, and emulsions of fats and oils. Such inclusion complexes are useful for the formulation of meal replacements in powder form and of dietary supplements [33]. However, one must keep in mind that hydrophilic CDs can act only as carrier materials for lipophilic guest molecules in oral administration by helping to transport them safely through an aqueous medium to the absorption surface of the gastrointestinal tract [66], thereby increasing their stability only until they permeate biological membranes of, for example, the intestinal epithelium.

Since CDs are poorly absorbed through biological membranes due to their relatively high molecular weight and large number of hydrogen donors and acceptors [4], it is not surprising that they usually do not increase the permeability of hydrophilic guest molecules through lipophilic biological membranes [4]. However, CDs can stabilize lipophilic guest molecules until they reach the unstirred water layer adjacent to the membrane surface of the biological barrier [4]. Generally, only a free form of the lipophilic guest molecule is able to penetrate the lipophilic biological membrane. Binding within the CD cavity is a reversible process, and the free and complexed forms of the drug are in equilibrium in solution [66]. This equilibrium is compound-specific. Accordingly, CDs cannot increase the bioavailability of every kind of molecule. For example, Class II drugs (Biopharmaceutics Classification System categories) have poor aqueous solubility, but show good membrane permeability. Here, complexation with CDs can enhance oral bioavailability by increasing diffusion to the mucosal surface. It has been reported that in this case, the most important factor inhibiting bioavailability is the low aqueous solubility of the drugs, which hinders their dissociation from the molecule as well as their permeation through the water layer adjacent to the membrane surface [4]. The bioavailability of Class I drugs cannot be improved by CDs. They are defined as highly water soluble and highly membrane permeable, and therefore have good bioavailability after oral administration [4]. Hence, such compounds are generally not encapsulated into CDs to enhance their bioavailability. A detailed review of drug absorption after oral administration and other application routes is given by Loftsson et al. [4] and Uekama et al. [66].

Regarding the use of CDs in pharmaceutical products to form complexes with lipophilic drugs, parenteral application also matters. It should be noted that parenteral administration is mainly suitable for $\beta C D$ derivatives such as HP $\beta C D$. $\alpha C D$ and $\beta C D$ are not recommended because of their reported nephrotoxicity. The low aqueous solubility of $\beta C D$ is also not an advantage for its use as a parenteral drug [49]. Similarly, $\gamma \mathrm{CD}$, which forms visible aggregates in aqueous solutions, is not suitable for parenteral formulations [21]. Furthermore, CDs have a short half-life in systemic circulation and a high excretion rate in urine, as described above. In the short time in systemic circulation, the complex may not reach its target organ. Otherwise, the complex may dissociate before it reaches the drug target organ or tissue [66]. 
Table 1. Bioavailability and bioactivity of inclusion complexes of tocotrienols, pentacyclic triterpenoids, propolis, and curcumin with $\gamma$-cyclodextrin.

\begin{tabular}{|c|c|c|c|c|c|c|}
\hline Substances and Cyclodextrins & Molar Ratio & Model Organism & Administration & Dose & Outcome & Authors \\
\hline $\begin{array}{c}\text { Tocotrienol }(\mathrm{T} 3) \text { and } \\
\gamma \text {-cyclodextrin }(\gamma \mathrm{CD})\end{array}$ & & $\begin{array}{l}\text { Wistar rats } \\
\mathrm{n}=5-8\end{array}$ & Oral & $13.9 \mathrm{mg}$ T3 & $\begin{array}{c}\text { Improved solubility and stability } \\
\text { in the GIT; } \\
\text { enhanced intestinal absorption } \\
\text { of T3; } \\
\text { increased plasma and tissue } \\
\text { concentration of T3 }\end{array}$ & Ikeda et al. 2014 [67] \\
\hline $\begin{array}{l}\text { T3-rich fraction (TRF) from rice } \\
\text { bran and } \gamma \mathrm{CD}\end{array}$ & & $\begin{array}{c}\text { C57BL } / 6 \text { mice } \\
\mathrm{n}=3 \text { (bioavailability) } \\
\mathrm{n}=12-15 \\
\text { (bioactivity) }\end{array}$ & Oral & $2.79 \mathrm{mg}$ TRF & $\begin{array}{l}\text { 1.4-fold increase of AUC of T3 } \\
\text { plasma concentration; } \\
\text { improved bioavailability and } \\
\text { physiological activity }\end{array}$ & Miyoshi et al. 2011 [22] \\
\hline $\mathrm{T} 3$ and $\gamma \mathrm{CD}$ & & $\begin{array}{l}\text { Caenorhabditis elegans } \\
\mathrm{n}=30 \text { worms per } \\
\text { group/duplicates, } \\
\text { performed two or } \\
\text { three times }\end{array}$ & Oral & 26,86 , and $259 \mu \mathrm{g} \mathrm{T} 3$ & Prolonged lifespan & Kashima et al. 2012 [68] \\
\hline $\mathrm{T} 3$ and $\gamma \mathrm{CD}$ & & $\begin{array}{l}\text { C57BL } / 6 \text { mice } \\
n=6-8\end{array}$ & Oral & $100 \mathrm{mg} \mathrm{T} 3 / \mathrm{kg}$ diet & $\begin{array}{c}\text { Increased mitochondrial } \\
\text { membrane potential and ATP } \\
\text { levels in aging brain }\end{array}$ & Schloesser et al. 2015 [69] \\
\hline $\begin{array}{c}\text { Ursolic acid (UA) \& oleanolic acid } \\
\text { (OA) \& 2-hydroxypropyl- } \gamma \text { CD } \\
\text { (HP- } \gamma \text { CD) }\end{array}$ & & $\begin{array}{l}\text { SKH1 mice } \\
\quad \mathrm{n}=6\end{array}$ & Dermal & $\begin{array}{l}200 \mu \mathrm{L} 2 \% \text { aqueous } \\
\text { solution }\end{array}$ & $\begin{array}{l}\text { No modification in TWL; } \\
\text { increased skin-pH; } \\
\text { small change of erythema; } \\
\text { small difference in stratum } \\
\text { corneum moisture content; } \\
\text { anti-tumor activity }\end{array}$ & Soica et al. 2014 [53] \\
\hline Betulin (Bet) and octakis- $\gamma C D$ & $1: 1$ & $\begin{array}{l}\text { C57BL/6 mice } \\
n=5\end{array}$ & $\begin{array}{l}\text { Subcutaneous } \\
\text { injection }\end{array}$ & $20 \mathrm{mg}$ Bet/BW & $\begin{array}{l}\text { Decreased tumor volume; } \\
\text { decreased tumor weight }\end{array}$ & Soica et al. 2012 [54] \\
\hline $\begin{array}{l}\text { Betulinic acid (BA) and } \\
\text { octakis- } \gamma \text { CD }\end{array}$ & $1: 1$ & $\begin{array}{l}\text { C57BL/6 mice } \\
\mathrm{n}=10\end{array}$ & $\begin{array}{l}\text { Subcutaneous } \\
\text { injection }\end{array}$ & $100 \mathrm{mg} \mathrm{BA} / \mathrm{kg}$ & $\begin{array}{c}\text { Decreased tumor volume; } \\
\text { decreased tumor weight; } \\
\text { decreased melanin, erythema, and } \\
\text { TWL levels }\end{array}$ & Soica et al. 2014 [52] \\
\hline $\mathrm{UA}$ and $\gamma \mathrm{CD}$ & & $\begin{array}{l}\text { Wistar rats } \\
\quad \mathrm{n}=6\end{array}$ & Intragastric & $20 \mathrm{mg}$ UA & $\begin{array}{c}\text { Increased liver regeneration; } \\
\text { increased hepatocyte growth } \\
\text { factor liver expression and plasma } \\
\text { levels }\end{array}$ & Žaloudková et al. 2020 [70] \\
\hline
\end{tabular}


Table 1. Cont.

\begin{tabular}{|c|c|c|c|c|c|c|}
\hline Substances and Cyclodextrins & Molar Ratio & Model Organism & Administration & Dose & Outcome & Authors \\
\hline Kuding tea extract (KTE) and $\gamma \mathrm{CD}$ & $1: 2$ & $\begin{array}{l}\text { C57BL } / 6 \text { mice } \\
\mathrm{n}=8-10\end{array}$ & Oral & $\begin{array}{c}7.12 \% \mathrm{KTE} \\
\text { (comprising } 0.15 \% \mathrm{UA} \text { ) }\end{array}$ & $\begin{array}{c}\text { Increased liver weight; } \\
\text { elevated hepatic fat accumulation; } \\
\text { increased hepatic PPAR } \gamma, \text { CD36, } \\
\text { CYP7A1, CYP3A, and GSTA1 } \\
\text { levels; } \\
\text { increased plasma cholesterol level }\end{array}$ & Wüpper et al. 2020 [71] \\
\hline $\begin{array}{c}\text { Brazilian green propolis } \\
\text { supercritical extract (GPSE) and } \\
\gamma \mathrm{CD}\end{array}$ & & $\begin{array}{l}\text { C57BL } / 6 \text { mice } \\
n=10\end{array}$ & Oral & $\begin{array}{l}2.3 \mathrm{~g} / \mathrm{kg} \text { GPSE- } \gamma \mathrm{CD} \\
\text { (providing } 200 \mathrm{mg} \\
\text { artepillin C } / \mathrm{kg} \text { diet) }\end{array}$ & $\begin{array}{c}\text { Decreased hepatic TNF } \alpha \text { and Sap } \\
\text { mRNA level; } \\
\text { anti-inflammatory properties }\end{array}$ & Rimbach et al. 2017 [72] \\
\hline $\begin{array}{l}\text { Caffeic acid phenethyl ester } \\
\text { (CAPE) and } \gamma \mathrm{CD}\end{array}$ & $1: 1$ & $\begin{array}{l}\text { Balb/c nude mice } \\
\qquad \mathrm{n}=9\end{array}$ & $\begin{array}{c}\text { Oral or } \\
\text { intraperitoneal }\end{array}$ & & $\begin{array}{l}\text { Decreased tumor volume; } \\
\text { anti-metastatic properties }\end{array}$ & Wadhwa et al. 2016 [73] \\
\hline CAPE and $\gamma \mathrm{CD}$ & & $\begin{array}{l}\text { A549 and HT1080 } \\
\text { cells }\end{array}$ & & & $\begin{array}{c}\text { Higher cytotoxicity; } \\
\text { higher solubility in a mimicked } \\
\text { intestinal environment }\end{array}$ & Ishida et al. 2018 [23] \\
\hline GPSE and $\gamma$ CD & $1: 1$ & $\begin{array}{l}\text { BALB / c nude mice } \\
\qquad \mathrm{n}=3\end{array}$ & Oral & $\begin{array}{c}\text { GPSE- } \gamma \text { CD (containing } \\
3 \% \text { artepillin C) }\end{array}$ & Decreased tumor growth & Bhargava et al. 2018 [74] \\
\hline Curcuminoids and $\gamma \mathrm{CD}$ & & $\begin{array}{l}\text { Humans } \\
\mathrm{n}=12\end{array}$ & Oral & $\begin{array}{c}371.4 \mathrm{mg} \text { total } \\
\text { curcuminoids } \\
\text { (containing } 346 \mathrm{mg} \\
\text { curcumin) }\end{array}$ & $\begin{array}{l}\text { Improved solubility and stability } \\
\text { in the GIT; } \\
\text { enhanced intestinal absorption of } \\
\text { T3 } \\
\text { increased plasma and tissue } \\
\text { concentration of T3 }\end{array}$ & Purpura et al. 2018 [76] \\
\hline
\end{tabular}

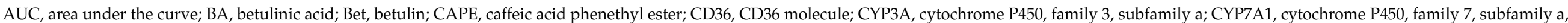

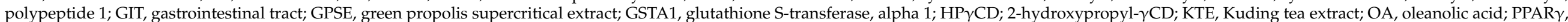

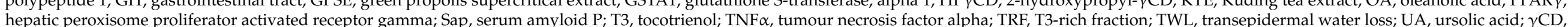
gamma-cyclodextrin. 


\subsection{Inclusion of Tocotrienol in $\gamma$-Cyclodextrin Increased Its Bioavailability and Bioactivity}

A study in male Wistar rats examined the effects of different tocotrienol emulsions (13.9 mg tocotrienol) with or without $\gamma \mathrm{CD}$ on $\gamma$-tocotrienol (for chemical structure, see Figure 5) concentrations in plasma and tissues. At $3 \mathrm{~h}$ after the oral administration of tocotrienol, tocotrienol with $\gamma \mathrm{CD}$, or tocotrienol $/ \gamma \mathrm{CD}$-complex, the complex of tocotrienol with $\gamma \mathrm{CD}$ led to elevated plasma and tissue concentrations of $\gamma$-tocotrienol compared to the simultaneous administration of tocotrienol and $\gamma \mathrm{CD}$. The authors suggested that complexation causes improved solubility and stability of tocotrienol in the gastrointestinal tract, thereby enhancing its intestinal absorption. Pretreatment with the detergent Triton and subsequent oral gavage of the different emulsions verified this suggestion in the laboratory rodents. The rats that were given the Triton complex exhibited higher plasma $\gamma$ tocotrienol concentrations than the animals in the other two groups. The study also clarified that the tissue accumulation of tocotrienol is less regulated than plasma concentration [67]. It has also been demonstrated that the inclusion of $\gamma$-tocotrienol in $\gamma \mathrm{CD}$ significantly improved the oral bioavailability and physiological activity of $\gamma$-tocotrienol in young C57BL/ 6 mice. The mice of the control group received $2.79 \mathrm{mg}$ of a $\gamma$-tocotrienol-rich fraction extracted from rice bran, while the complex group obtained an equivalent dose of the $\gamma$-tocotrienol-rich fraction included in $\gamma \mathrm{CD}$. Complexation led to a 1.4-fold increase in the area under the curve of $\gamma$-tocotrienol plasma concentration compared to the $\gamma$ tocotrienol-rich fraction only [22]. In addition, the complexation of tocotrienols with $\gamma \mathrm{CD}$ resulted in a prolonged life span in the nematode Caenorhabditis elegans compared to worms receiving pure $\gamma \mathrm{CD}$ or pure tocotrienols. Initially, it was observed that the nematodes absorbed a fluorescent dye, which was encapsulated in $\gamma \mathrm{CD}$ for this assay, from the gastrointestinal tract and accumulated the dye in the cytoplasm of the intestinal cells. After testing the ingestion of $\gamma \mathrm{CD}$ inclusion compounds, the oral administration of tocotrienols in $\gamma \mathrm{CDs}$ was analyzed. Accordingly, the authors suggested that $\gamma \mathrm{CD}$ is an excellent vehicle for the oral gavage of hydrophobic substances such as tocotrienol [68]. Schloesser et al. [69] evaluated the effect of a dietary tocotrienol- $\gamma \mathrm{CD}$ complex on an ageing brain phenotype in mice. Male middle-aged C57BL/6J mice received a high-fat, high-sugar Western-type diet with or without (control) tocotrienol- $\gamma \mathrm{CD}$ complex for up to 24 weeks. The tocotrienol content was $100 \mathrm{mg} / \mathrm{kg}$ diet. Examination of the brain revealed significantly increased mitochondrial membrane potential and ATP levels in the complex mice compared to the controls [69]. Unfortunately, the authors did not include a control group with tocotrienols only.

In summary, tocotrienol exhibits improved bioavailability through enhanced solubility and stability in the gastrointestinal tract, and therefore enhanced bioactivity in various laboratory model organisms, attributable to encapsulation into CDs.

\subsection{Pentacyclic Triterpenoids Encapsulated in $\gamma$-Cyclodextrin}

Pentacyclic triterpenoids such as UA have been reported to act as chemopreventive agents $[77,78]$. However, due to their low solubility and limited oral bioavailability [79], new approaches, such as encapsulation into CDs, have been introduced to enhance bioavailability and bioactivity. Several cell culture studies have demonstrated that complex formulations of triterpenoids and CDs could improve the anticancer activity of triterpenoids $[24,51,53,80]$. This seems somewhat questionable, especially when looking at studies where a significant effect was shown in vivo, but not in vitro [52,54]. However, a possible explanation for the improved in vitro anticancer activity might be that CDs enhance the cellular uptake of drugs [24] by simply increasing their solubility in aqueous media.

Soica et al. [53] found synergistic antiproliferative activity of a mixture of OA and UA (for chemical structure, see Figure 5) encapsulated in 2-hydroxypropyl- $\gamma$-cyclodextrin $(\mathrm{HP} \gamma \mathrm{CD})$ when applied in a chemically $(7,12$-dimethylbenz(a)-anthracene/12-O-tetradecan oyl-phorbol-13-acetate) induced and UV-induced murine skin cancer model. SKH1 female mice were treated $30 \mathrm{~min}$ before the application of carcinogens with either $200 \mu \mathrm{L}$ of a $2 \%$ 
aqueous solution of OA-HP $\gamma \mathrm{CD}$, UA-HP $\gamma \mathrm{CD}$, or OA/UA-HP $\gamma \mathrm{CD}$. The delta of transepidermal water loss (TWL) was in the control group at approximately 25 units/six weeks. The mice treated with UA-HP $\gamma \mathrm{CD}$ and OA/UA-HP $\gamma \mathrm{CD}$ showed practically no modification in TWL. The application of OA/UA-HP $\gamma \mathrm{CD}$ led to the greatest increase in skin $\mathrm{pH}$. The evaluation of erythema, an important skin parameter involved in the assessment of drug or chemical irritative potential, indicated a change of more than 230 units after six weeks for the control group. However, only a small difference was documented for the mice who received UA-HP $\gamma \mathrm{CD}$ or OA/UA-HP $\gamma \mathrm{CD}$. Similar results were reported for water loss from the stratum corneum [53].

Betulin (Bet) and betulinic acid (BA) (Figure 5) were encapsulated in octakis-[6-deoxy6-(2-sulfanyl ethanesulfonate) $]-\gamma C D(O \gamma C D)$, a $\gamma C D$ derivative, to analyze their antitumor activity in a B164A5/C57BL/6J mouse melanoma model [52,54]. At 2 days after the inoculation of B164A5 cells in mice, the Bet-O $\gamma \mathrm{CD}$ complex was given intraperitoneally

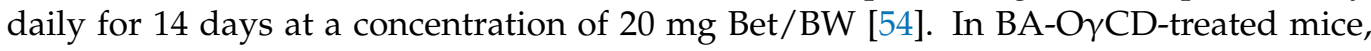
the complex was administered intraperitoneally 1 day after cell inoculation at a dose of $100 \mathrm{mg} / \mathrm{kg}$ daily for 3 weeks [52]. Both treatments significantly inhibited tumor growth in mice compared to that in untreated laboratory animals [52,54]. BA-O $\gamma \mathrm{CD}$ administration further led to decreased melanin, erythema, and TWL levels compared to control mice [52]. Natural sources of UA (homogenate apple peel, HAP, and micronized apple peel, MAP) were compared with encapsulated UA in $\beta C D$ and $\gamma C D$, respectively, regarding their impact on liver regeneration. Therefore, male Wistar rats received $20 \mathrm{mg}$ UA daily for 7 days via intragastric gavage. On day 6, a partial hepatectomy $(70 \%)$ was conducted. UA-treated rats showed increased liver regeneration in comparison to untreated mice. In particular, the UA complex with $\gamma \mathrm{CD}$ exhibited good results. Plasma levels and expression of hepatocyte growth factor in the liver were significantly increased in the high-fat dietUA- $\gamma$ CD group compared to the control group [70].

However, in a study that used dietary Kuding tea extract as a UA source (KTE, 7.12\%) encapsulated in $12.88 \% \gamma \mathrm{CD}$ (comprising $150 \mathrm{mg} \mathrm{UA} / \mathrm{kg} \mathrm{BW}$ ), young male C57BL/6 mice had increased liver weight and hepatic fat accumulation compared to control mice, which received only a high-fat, high-fructose, Western-type diet for 6 weeks. In addition, the mice from the complex group showed increased hepatic peroxisome proliferator activated receptor gamma (Ppary) and CD36 molecule (Cd36) mRNA levels as well as elevated plasma cholesterol levels and increased cytochrome P450, family 7, subfamily a, polypeptide 1 (CYP7A1) mRNA, and protein levels. Analyzing the enzymes of hepatic xenobiotic metabolism showed that there was a substantial elevation of cytochrome P450, family 3 , subfamily a (CYP3A) and glutathione S-transferase, alpha 1 (GSTA1) mRNA, and protein levels in KTE- $\gamma$ CD mice. Pure UA-treated mice exhibited a moderate elevation of CYP3A and GSTA1. In line with the assumption that CDs can mask the taste of guest molecules [3], the study demonstrated that mice receiving a diet with bitter-tasting KTE alone completely refused this diet, while the diet supplemented with KTE- $\gamma \mathrm{CD}$ was eaten by mice [71]. This study may show the other side of the coin of some inclusion complex formulations. By encapsulating bioactive compounds, one may not only increase their positive biological effects, but also promote some adverse effects, such as hepatotoxicity.

\subsection{Propolis, Propolis Extract, or Phytochemicals Isolated from Propolis Encapsulated in $\gamma$-Cyclodextrin}

Brazilian green propolis supercritical extract (GPSE) has been reported to be rich in artepillin C (3,5-diprenyl-4 hydroxycinnamic acid, Figure 5) and to stimulate immune function. Accordingly, dietary GPSE encapsulated in $\gamma \mathrm{CD}(2.3 \mathrm{~g} / \mathrm{kg}$ GPSE- $\gamma \mathrm{CD})$ showed anti-inflammatory properties in female C57BL/ 6 mice after 10 weeks of supplementation. Hepatic gene expression of tumor necrosis factor alpha (TNF $\alpha$ ) and serum amyloid P (Sap) was significantly decreased in GPSE- $\gamma$ CD-fed mice compared to the control group and the $\gamma \mathrm{CD}$-vehicle group, respectively [72]. Moreover, there are several reports on propolis in combination with $\gamma \mathrm{CD}$ and its anticancer and antimetastatic activities [73-75]. Caffeic acid phenethyl ester (CAPE, Figure 4), a key phenolic component in New Zealand propo- 
lis, showed antitumor and antimetastatic potency in female Balb/c nude mice, and the complexation of CAPE with $\gamma$ CD enhanced its activities. $\gamma C D$ per se did not exhibit any bioactivity. The human fibrosarcoma cell line HT1080 was injected subcutaneously into the abdomen of mice and into the tail vein. Starting one day after injection, treatment with CAPE or CAPE- $\gamma$ CD was performed on every alternate day. Mice received either intraperitoneal or oral administration of CAPE for up to 30 days. For both routes of administration, CAPE showed significant tumor suppression and reduction in lung metastasis. CAPE- $\gamma$ CD-treated mice exhibited increased antitumor and antimetastatic activities compared to pure CAPE [73]. According to the findings by Wadhwa et al. [73], in an in vitro cell viability assay, CAPE- $\gamma$ CD revealed higher cytotoxicity in A549 and HT1080 cells than CAPE alone [23]. In addition, the comparison of CAPE and CAPE- $\gamma$ CD solubility in $1.0 \%$ taurocholic acid solution showed that complexation with $\gamma C D$ increased the solubility of CAPE in a mimicked intestinal environment [23], possibly resulting in higher tumor suppression activity, as reported in an earlier study [73]. In this context, it is interesting that CAPE alone is vulnerable to digestive enzymes such as secreted esterases. However, when encapsulated in $\gamma \mathrm{CD}, \mathrm{CAPE}$ is protected and shows enhanced activity [73]. The antitumor properties of GPSE from Brazilian green propolis were also examined. GPSE, containing $9.6 \%$ artepillin C and GPSE- $\gamma$ CD, containing $3 \%$ artepillin C, was orally administered to $\mathrm{BALB} / \mathrm{c}$ nude mice beginning 1 day after subcutaneous tumor xenografts for 3 weeks. The authors observed decreased tumor growth in mice fed GPSE and GPSE- $\gamma$ CD compared to untreated mice. The data on GPSE alone and with $\gamma \mathrm{CD}$ regarding tumor growth suggested that complexation results in a more effective molecule [74].

Cho et al. [75] reported on C57BL/6J-ApcMin/+/J mice that received either a control diet for a lean model or a high-fat diet for an obese model supplemented with $\gamma C D$ and propolis (containing $\gamma \mathrm{CD}$ ), for 8 weeks. The chosen mouse model tends to develop intestinal cancer with adenomas. In the lean model, $\gamma \mathrm{CD}$ and propolis-treated mice showed decreased neoplastic progression. Supplementation with propolis led to a further decrease in the number of adenomas compared to the control diet [75]. However, since $\gamma \mathrm{CD}$ also affects intestinal tumor development, it is not exactly clear what part propolis plays in this effect.

\subsection{Increased Bioavailability of Curcumin by Complexation with $\gamma$-Cyclodextrin in Humans}

Curcumin (Figure 5) is the main bioactive hydrophobic polyphenolic compound from the so-called curcuminoids provided by turmeric, a member of the ginger family $[76,81]$. Previous studies have shown that curcumin possesses various pharmacological activities, such as antioxidant, anti-inflammatory, and neuroprotective properties [82]. However, the metabolism of curcumin, particularly in the intestine and liver, determines its bioavailability and bioactivity [81]. Due to the low water solubility and poor intestinal absorption of curcumin, different formulations have been developed to enhance its bioavailability [76]. In this context, Purpura et al. [76] analyzed the pharmacokinetics of a standardized unformulated curcumin extract (StdC), a $\gamma$ CD-curcumin formulation (C- $\gamma \mathrm{CD})$, a curcumin phytosome formulation, and a curcumin formulation with essential oils of turmeric extracted from the rhizome in a double-blind, crossover study in 12 healthy human subjects. The curcumin content in C- $\gamma \mathrm{CD}$ was determined to be $348 \mathrm{mg}$. In addition, the complex formulation contained demethoxycurcumin and bisdemethoxycurcumin, resulting in a total curcuminoid content of $371 \mathrm{mg}$. Complexation with $\gamma \mathrm{CD}$ significantly increased the bioavailability of curcumin (85-fold) and total curcuminoids (39-fold) compared to StdC. Plasma levels of curcuminoids were measured by HPLC-MS/MS analysis up to $12 \mathrm{~h}$ after the intake of hard gel capsules of each of the different curcumin formulations. The peak concentration of curcumin from C- $\gamma$ CD in plasma was $73 \mathrm{ng} / \mathrm{mL}$, achieved after $1 \mathrm{~h}$. However, the peak curcumin concentration after StdC intake was $0.5 \mathrm{ng} / \mathrm{mL}$ after $12 \mathrm{~h}$ [76]. 


\subsection{Metabolic Activity of Empty $\gamma$-Cyclodextrin}

As mentioned above, the propolis- $\gamma \mathrm{CD}$ study by Cho et al. [75] also revealed an unexpected beneficial effect of $\gamma \mathrm{CD}$ supplementation per se. C57BL/6J-ApcMin/+/J mice were fed either a control diet for a lean model or a high-fat diet for an obese model supplemented with $\gamma \mathrm{CD}$ and propolis (containing $\gamma \mathrm{CD}$ ) for 8 weeks. Both control groups treated with $\gamma \mathrm{CD}$ showed modulation of intestinal tumor development. In the obese state, dietary $\gamma \mathrm{CD}$ led to the lowest number and size of adenomas and concurrent to the highest percentage of lesions with low grades of dysplasia in mice. Interestingly, the laboratory animals supplemented with propolis (containing $\gamma \mathrm{CD}$ ) did not show this reduction in neoplastic burden, indicating that propolis counteracted these effects. It has been assumed that the effect of dietary $\gamma \mathrm{CD}$ resulted from enhanced levels of apoptosis in intestinal tissue, achieved by butyrate derived from $\gamma \mathrm{CD}$ metabolism [75].

Another interesting biological effect of empty $\gamma \mathrm{CD}$ was provided by Asp et al. [44]. Thirty-two healthy adult subjects received $50 \mathrm{~g}$ of carbohydrate from either $\gamma \mathrm{CD}$ or maltodextrin during a double-blind, randomized crossover study. Plasma glucose and serum insulin levels were reported for up to $180 \mathrm{~min}$ postprandial. Intake of $\gamma \mathrm{CD}$ led to a moderate and gradual increase in both glycaemia parameters. The area under the curve (AUC) of plasma glucose was $45 \%$ reduced compared to maltodextrin. Consequently, the AUC of serum insulin was reduced by $49 \%$ by $\gamma \mathrm{CD}$ compared to maltodextrin. Monitored breath hydrogen excretion showed no differences between the two carbohydrate sources, indicating that $\gamma \mathrm{CD}$ is fully hydrolyzed in the small intestine. In comparison with rapidly digested maltodextrin, $\gamma \mathrm{CD}$ is assumed to be a slowly digested carbohydrate, resulting in reduced postprandial glycaemia [44]. In line with this assumption, it has been reported that dietary $\gamma \mathrm{CD}$ leads to increased endurance in C57BL/ 6 mice, probably due to a prolonged supply of glucose during exercise. The laboratory animals received a control diet or a diet supplemented with $12.88 \% \gamma \mathrm{CD}$ for 6 weeks. Voluntary activity was monitored via the wheel running behavior of mice. The $\gamma \mathrm{CD}$-treated animals covered a significantly larger distance per night and were active significantly longer during the night than the control mice. Furthermore, adding $\gamma \mathrm{CD}$ to the diet led to a significantly better performance of mice in the inverted screen test, suggesting that these animals showed enhanced muscle strength. It was also observed that dietary $\gamma \mathrm{CD}$ had some slight antiglycemic effects [83].

The existing literature data demonstrate that the $\gamma \mathrm{CD}$ derivative $\mathrm{HP} \gamma \mathrm{CD}$ may act as a therapeutic approach for Niemann-Pick type C disease (NPC) [84-88], which is a fatal neurodegenerative disorder characterized by a massive accumulation of free cholesterol and other lipids in late endosomes and lysosomes. In addition, NPC1-deficient cells showed defects in autophagy [89,90]. In line with this assumption, it has been reported that $\mathrm{HP} \gamma \mathrm{CD}$ alleviates cholesterol accumulation in NPC1 patient-derived fibroblasts by modulating lysosomal dynamics and functions as well as enhancing autophagic activity $[84,85,87,91]$. The cholesterol-binding capacity of $\mathrm{HP} \gamma \mathrm{CD}$ is still lower than that of $\mathrm{HP} \beta C D[86,91]$, but the same applies for its ototoxicity [86]. Therefore, $\mathrm{HP} \gamma \mathrm{CD}$ might be a more promising drug candidate than $\mathrm{HP} \beta C D$ for the treatment of NPC. In particular, $\mathrm{HP} \gamma \mathrm{CD}$ alleviates lysosomal cholesterol accumulation in NPC1-deficient cells to the same degree as HP $\beta C D$ [84], or even more effectively [87]. Moreover, liver dysfunction and cholesterol accumulation were enhanced by the subcutaneous injection of $\mathrm{HP} \gamma \mathrm{CD}$ in NPC model mice [87]. Recent molecular research has indicated that the effects of $\mathrm{HP} \gamma \mathrm{CD}$ are partly mediated by transcription factor EB, which is a regulator of lysosomal functions and autophagy [84]. However, the underlying mechanism of action remains to be clarified. Hoque et al. [88] showed that both HP $\beta C D$ and $\mathrm{HP} \gamma \mathrm{CD}$ (but not $\mathrm{HP} \alpha \mathrm{CD}$ ) reduced cholesterol and sphingolipid accumulation solely in Npc1-null Chinese hamster ovary cells, but not in the corresponding control wild-type cells.

\section{Conclusions and Outlook}

Increasing the stability, bioavailability, and bioactivity of natural compounds and plant bioactives is an important issue in food science and pharmaceutics. As reviewed 
here, this goal can be achieved by encapsulating these often lipophilic molecules in $\gamma \mathrm{CD}$. A growing number of studies indicate that such CD complexes often lead to enhanced biological/pharmacological efficiency, increased stability, and better taste and odor.

However, one should consider that improving the bioavailability of dietary plant bioactives may be accompanied by some risks, and a critical evaluation as well as a risk assessment is needed. Encapsulation enables the intake of higher dosages of natural compounds and plant bioactives. As shown for KTE encapsulated in $\gamma \mathrm{CD}$, high dietary supplementation can lead to an increased hepatic phase I and phase II response [71]. Hence, improving the bioavailability of plant bioactives that undergo biotransformation can cause hepatotoxicity due to exceeding the toxicity threshold or can lead to herb-drug interactions, thereby affecting medical treatment [92]. In this regard, it is notable that the number of liver injury cases in the United States associated with dietary supplementation of herbal sources is actually increasing [93].

Similarly, the complexation of natural products such as the bee product propolis could also increase the bioavailability of potential allergens. Propolis allergies per se were more of an occupational disease affecting beekeepers in the past. However, since propolis is frequently included in dietary supplements, more and more, an increasing number of people are affected by this allergy [94].

Moreover, by complexing herbal extracts into CDs, one may increase the bioavailability of undesirable substances such as pesticides or contaminants. The selection and quality of the raw material is therefore of particular importance. It should also be considered that CDs mask the bitter taste and odor of their complexation agents, as reported for KTE. A bitter taste often results in food aversion by animals, thereby protecting them against the consumption of toxic compounds, although not all bitter compounds are toxic [95].

CDs have a long history as host molecules in inclusion complexes and were long presumed to be inert molecules. However, only recently has it become evident that CDs are not just carrier molecules, but also undergo digestion and fermentation in the digestive tract. In particular, the first studies on $\gamma \mathrm{CD}$ supplementation revealed promising effects on energy metabolism. Therefore, the impact of empty CDs on metabolism and their possible nutritional or pharmaceutical applications need additional investigation.

Author Contributions: Conceptualization, S.W., K.L., and G.R.; methodology, S.W.; investigation, S.W.; writing—original draft preparation, S.W.; writing—review and editing, S.W., K.L., and G.R.; visualization, S.W.; supervision, G.R.; project administration, G.R.; funding acquisition, S.W. All authors have read and agreed to the published version of the manuscript.

Funding: The authors acknowledge the financial support by Land Schleswig-Holstein within the funding program "Open Access Publikationsfonds".

Institutional Review Board Statement: Not applicable.

Informed Consent Statement: Not applicable.

Data Availability Statement: Data sharing not applicable.

Conflicts of Interest: G.R. has received funding from CycloChem Bio Co., Ltd., a company selling cyclodextrins in previous studies.

\section{References}

1. Li, Z.; Wang, M.; Wang, F.; Gu, Z.; Du, G.; Wu, J.; Chen, J. $\gamma$-Cyclodextrin: A review on enzymatic production and applications. Appl. Microbiol. Biotechnol. 2007, 77, 245-255. [CrossRef]

2. Del Valle, E. Cyclodextrins and their uses: A review. Process. Biochem. 2004, 39, 1033-1046. [CrossRef]

3. Singh, M.; Sharma, R.; Banerjee, U. Biotechnological applications of cyclodextrins. Biotechnol. Adv. 2002, 20, 341-359. [CrossRef]

4. Loftsson, T.; Jarho, P.; Másson, M.; Järvinen, T. Cyclodextrins in drug delivery. Expert Opin. Drug Deliv. 2005, 2, 335-351. [CrossRef]

5. Saokham, P.; Loftsson, T. $\gamma$-Cyclodextrin. Int. J. Pharm. 2017, 516, 278-292. [CrossRef]

6. Crini, G. Review: A history of cyclodextrins. Chem. Rev. 2014, 114, 10940-10975. [CrossRef] [PubMed]

7. Booij, L.H.D.J. Cyclodextrins and the emergence of sugammadex. Anaesthesia 2009, 64, 31-37. [CrossRef]

8. Szejtli, J. Introduction and general overview of cyclodextrin chemistry. Chem. Rev. 1998, 98, 1743-1754. [CrossRef] [PubMed] 
9. French, D. Preparation of Schardinger Dextrins. In Methods Enzymology; Elsevier: Amsterdam, The Netherlands, 1957; Volume 3, pp. 17-20.

10. Pulley, A.O.; French, D. Studies on the Schardinger dextrins. XI: The isolation of new Schardinger dextrins. Biochem. Biophys. Res. Commun. 1961, 5, 11-15. [CrossRef]

11. Braga, S.S. Cyclodextrins: Emerging medicines of the new millennium. Biomolecules 2019, 9, 801. [CrossRef]

12. Van Der Veen, B.A.; Van Alebeek, G.-J.W.M.; Uitdehaag, J.C.M.; Dijkstra, B.W.; Dijkhuizen, L. The three transglycosylation reactions catalyzed by cyclodextrin glycosyltransferase from Bacillus circulans (strain 251) proceed via different kinetic mechanisms. Eur. J. Biochem. 2000, 267, 658-665. [CrossRef]

13. Biwer, A.; Antranikian, G.; Heinzle, E. Enzymatic production of cyclodextrins. Appl. Microbiol. Biotechnol. 2002, 59, 609-617. [CrossRef]

14. Uitdehaag, J.C.; Mosi, R.; Kalk, K.H.; van der Veen, B.A.; Dijkhuizen, L.; Withers, S.G.; Dijkstra, B.W. X-ray structures along the reaction pathway of cyclodextrin glycosyltransferase elucidate catalysis in the alpha-amylase family. Nat. Genet. 1999, 6, 432-436. [CrossRef]

15. Goo, B.G.; Hwang, Y.J.; Park, J.K. Bacillus thuringiensis: A specific gamma-cyclodextrin producer strain. Carbohydr. Res. 2014, 386, 12-17. [CrossRef] [PubMed]

16. Szejtli, J. Cyclodextrins. Clin. Drug Investig. 1990, 2, 11-21. [CrossRef]

17. Heredia, A.; Requena, G.; Garciasanchez, F. An approach for the estimation of the polarity of the $\beta$-cyclodextrin internal cavity. J. Chem. Soc. Chem. Commun. 1985, 1814-1815. [CrossRef]

18. Kajtár, M.; Vikmon, M.; Morlin, E.; Szejtli, J. Aggregation of amphotericin B in the presence of $\gamma$-cyclodextin. Biopolym. Orig. Res. Biomol. 1989, 28, 1585-1596. [CrossRef] [PubMed]

19. Street, K.W.; Acree, W.E. Estimation of the effective dielectric constant of cyclodextrin cavities based on the fluorescence properties of pyrene-3-carboxaldehyde. Appl. Spectrosc. 1988, 42, 1315-1318. [CrossRef]

20. Caira, M.R. Cyclodextrin inclusion of medicinal compounds for enhancement of their physicochemical and biopharmaceutical properties. Curr. Top. Med. Chem. 2019, 19, 2357-2370. [CrossRef]

21. Suvarna, V.; Gujar, P.; Murahari, M. Complexation of phytochemicals with cyclodextrin derivatives-An insight. Biomed. Pharm. 2017, 88, 1122-1144. [CrossRef]

22. Miyoshi, N.; Wakao, Y.; Tomono, S.; Tatemichi, M.; Yano, T.; Ohshima, H. The enhancement of the oral bioavailability of $\gamma$-tocotrienol in mice by $\gamma$-cyclodextrin inclusion. J. Nutr. Biochem. 2011, 22, 1121-1126. [CrossRef]

23. Ishida, Y.; Gao, R.; Shah, N.; Bhargava, P.; Furune, T.; Kaul, S.C.; Terao, K.; Wadhwa, R. Anticancer activity in honeybee propolis: Functional insights to the role of caffeic acid phenethyl ester and its complex with $\gamma$-cyclodextrin. Integr. Cancer 2018, 17, 867-873. [CrossRef]

24. Oprean, C.; Mioc, M.; Csányi, E.; Ambrus, R.; Bojin, F.; Tatu, C.; Cristea, M.; Ivan, A.; Danciu, C.; Dehelean, C.; et al. Improvement of ursolic and oleanolic acids' antitumor activity by complexation with hydrophilic cyclodextrins. Biomed. Pharm. 2016, 83, 1095-1104. [CrossRef]

25. Stella, V.J.; Rajewski, R.A. Cyclodextrins: Their future in drug formulation and delivery. Pharm. Res. 1997, 14, 556-567. [CrossRef] [PubMed]

26. Yuan, H.; Peng, Q.; Yong-Wei, W.; Dong-Sheng, Z.; Ming-Wan, Z.; Rui, L.; Nan, J. Host-guest interaction of $\beta$-cyclodextrin with isomeric ursolic acid and oleanolic acid: Physicochemical characterization and molecular modeling study. J. Biomed. Res. 2017, 31, 395-407. [CrossRef] [PubMed]

27. Fenyvesi, É.; Vikmon, M.; Szente, L. Cyclodextrins in food technology and human nutrition: Benefits and limitations. Crit. Rev. Food Sci. Nutr. 2016, 56, 1981-2004. [CrossRef]

28. Lovegrove, A.; Edwards, C.H.; De Noni, I.; Patel, H.; El, S.N.; Grassby, T.; Zielke, C.; Ulmius, M.; Nilsson, L.; Butterworth, P.J.; et al. Role of polysaccharides in food, digestion, and health. Crit. Rev. Food Sci. Nutr. 2017, 57, 237-253. [CrossRef]

29. Kubota, Y.; Fukuda, M.; Muroguchi, M.; Koizumi, K. Absorption, distribution and excretion of BETA-Cyclodextrin and glucosylBETA.-cyclodextrin in rats. Biol. Pharm. Bull. 1996, 19, 1068-1072. [CrossRef] [PubMed]

30. Van Ommen, B.; De Bie, A.; Bär, A. Disposition of 14C- $\alpha$-cyclodextrin in germ-free and conventional rats. Regul. Toxicol. Pharm. 2004, 39, 57-66. [CrossRef]

31. De Bie, A.; Van Ommen, B.; Bar, A. Disposition of [14C] $\gamma$-Cyclodextrin in germ-free and conventional rats. Regul. Toxicol. Pharm. 1998, 27, 150-158. [CrossRef] [PubMed]

32. Frijlink, H.W.; Visser, J.; Hefting, N.R.; Oosting, R.; Meijer, D.K.F.; Lerk, C.F. The pharmacokinetics of $\beta$-cyclodextrin and hydroxypropyl- $\beta$-cyclodextrin in the rat. Pharm. Res. 1990, 7, 1248-1252. [CrossRef] [PubMed]

33. Munro, I.; Newberne, P.; Young, V.; Bär, A. Safety assessment of $\gamma$-cyclodextrin. Regul. Toxicol. Pharm. 2004, 39, 3-13. [CrossRef] [PubMed]

34. Harangi, J.; Béke, G.; Harangi, M.; Mótyán, J.A. The digestable parent cyclodextrin. J. Incl. Phenom. Macrocycl. Chem. 2011, 73, 335-339. [CrossRef]

35. Lumholdt, L.R.; Holm, R.; Jørgensen, E.B.; Larsen, K.L. In Vitro investigations of $\alpha$-amylase mediated hydrolysis of cyclodextrins in the presence of ibuprofen, flurbiprofen, or benzo[a]pyrene. Carbohydr. Res. 2012, 362, 56-61. [CrossRef]

36. Frank, D.W.; Gray, J.E.; Weaver, R.N. Cyclodextrin nephrosis in the rat. Am. J. Pathol. 1976, 83, 367-382. [PubMed] 
37. Frijlink, H.W.; Eissens, A.C.; Hefting, N.R.; Poelstra, K.; Lerk, C.F.; Meijer, D.K.F. The effect of parenterally administered cyclodextrins on cholesterol levels in the rat. Pharm. Res. 1991, 8, 9-16. [CrossRef]

38. Lina, B.; Bär, A. Subchronic oral toxicity studies with $\alpha$-cyclodextrin in rats. Regul. Toxicol. Pharm. 2004, 39, 14-26. [CrossRef]

39. Lina, B.; Bär, A. Subchronic (13-week) oral toxicity study of $\alpha$-cyclodextrin in dogs. Regul. Toxicol. Pharm. 2004, 39, 27-33. [CrossRef]

40. Amar, M.J.A.; Kaler, M.; Courville, A.B.; Shamburek, R.; Sampson, M.; Remaley, A.T. Randomized double blind clinical trial on the effect of oral $\alpha$-cyclodextrin on serum lipids. Lipids Health Dis. 2016, 15, 1-8. [CrossRef]

41. Bellringer, M.; Smith, T.; Read, R.; Gopinath, C.; Olivier, P. $\beta$-Cyclodextrin: 52-week toxicity studies in the rat and dog. Food Chem. Toxicol. 1995, 33, 367-376. [CrossRef]

42. Til, H.; Bar, A. Subchronic (13-Week) oral toxicity study of $\gamma$-cyclodextrin in dogs. Regul. Toxicol. Pharm. 1998, 27, 159-165. [CrossRef]

43. Waalkens-Berendsen, D.; Verhagen, F.; Bär, A. Embryotoxicity and teratogenicity study with $\gamma$-cyclodextrin in rats. Regul. Toxicol. Pharm. 1998, 27, 166-171. [CrossRef]

44. Asp, M.L.; Hertzler, S.R.; Chow, J.; Wolf, B.W. Gamma-cyclodextrin lowers postprandial glycemia and insulinemia without carbohydrate malabsorption in healthy adults. J. Am. Coll. Nutr. 2006, 25, 49-55. [CrossRef]

45. GRAS Notice 678, Alpha-cyclodextrin. Available online: https://www.fda.gov/media/101653/download (accessed on 6 November 2020).

46. Wacker Biochem Corp. GRAS Notice 000046: GAMMA-CYCLODEXTRIN. Available online: http://wayback.archive-it.org/7993 /20171031055850/https:/ / www.fda.gov/downloads/Food/IngredientsPackagingLabeling/GRAS/NoticeInventory/UCM2 61675.pdf (accessed on 20 July 2020).

47. Loftsson, T.; Brewster, M.E. Pharmaceutical applications of cyclodextrins: Basic science and product development. J. Pharm. Pharm. 2010, 62, 1607-1621. [CrossRef]

48. Mortensen, A.; Aguilar, F.; Crebelli, R.; Di Domenico, A.; Dusemund, B.; Frutos, M.J.; Galtier, P.; Gott, D.; Gundert-Remy, U. Re-evaluation of $\beta$-cyclodextrin (E 459) as a food additive. EFSA J. 2016, 14, 257. [CrossRef]

49. European Medicines Agency. Background Review for Cyclodextrins Used as Excipients; European Medicines Agency: London, UK, 2014.

50. Hedges, A.R. Industrial applications of cyclodextrins. Chem. Rev. 1998, 98, 2035-2044. [CrossRef] [PubMed]

51. Sun, Y.-F.; Song, C.-K.; Viernstein, H.; Unger, F.; Liang, Z.-S. Apoptosis of human breast cancer cells induced by microencapsulated betulinic acid from sour jujube fruits through the mitochondria transduction pathway. Food Chem. 2013, 138, 1998-2007. [CrossRef] [PubMed]

52. Şoica, C.; Danciu, C.; Savoiu-Balint, G.; Borcan, F.; Ambrus, R.; Zupkó, I.; Bojin, F.; Coricovac, D.; Ciurlea, S.; Avram, S.; et al. Betulinic acid in complex with a gamma-cyclodextrin derivative decreases proliferation and In Vivo tumor development of non-metastatic and metastatic B164A5 Cells. Int. J. Mol. Sci. 2014, 15, 8235-8255. [CrossRef]

53. Soica, C.; Oprean, C.; Borcan, F.; Danciu, C.; Trandafirescu, C.; Coricovac, D.; Crainiceanu, Z.; Dehelean, C.A.; Munteanu, M. The synergistic biologic activity of oleanolic and ursolic acids in complex with hydroxypropyl- $\gamma$-cyclodextrin. Molecules 2014, 19, 4924-4940. [CrossRef]

54. Şoica, C.; Dehelean, C.; Danciu, C.; Wang, H.M.; Wenz, G.; Ambrus, R.; Bojin, F.; Anghel, M. Betulin complex in $\gamma$-cyclodextrin derivatives: Properties and antineoplasic activities in In Vitro and In Vivo tumor models. Int. J. Mol. Sci. 2012, 13, 14992-15011. [CrossRef]

55. Stella, V.J.; He, Q. Cyclodextrins. Toxicol. Pathol. 2008, 36, 30-42. [CrossRef]

56. Aytac, Z.; Ipek, S.; Durgun, E.; Tekinay, T.; Uyar, T. Antibacterial electrospun zein nanofibrous web encapsulating thymol/cyclodextrin-inclusion complex for food packaging. Food Chem. 2017, 233, 117-124. [CrossRef]

57. Friné, V.-C.; Hector, A.-P.; Manuel, N.-D.S.; Estrella, N.-D.; Antonio, G.J. Development and characterization of a biodegradable PLA food packaging hold monoterpene-cyclodextrin complexes against alternaria alternata. Polymers 2019, 11, 1720. [CrossRef]

58. Al-Nasiri, G.; Cran, M.J.; Smallridge, A.J.; Bigger, S.W. Optimisation of $\beta$-cyclodextrin inclusion complexes with natural antimicrobial agents: Thymol, carvacrol and linalool. J. Microencapsul. 2017, 35, 26-35. [CrossRef]

59. Das, S.; Gazdag, Z.; Szente, L.; Meggyes, M.; Horváth, G.; Lemli, B.; Kunsági-Máté, S.; Kuzma, M.; Kőszegi, T. Antioxidant and antimicrobial properties of randomly methylated $\beta$ cyclodextrin-Captured essential oils. Food Chem. 2019, 278, 305-313. [CrossRef] [PubMed]

60. Wicochea-Rodríguez, J.D.; Chalier, P.; Ruiz, T.; Gastaldi, E. Active food packaging based on biopolymers and aroma compounds: How to design and control the release. Front. Chem. 2019, 7, 398. [CrossRef] [PubMed]

61. Higueras, L.; López-Carballo, G.; Hernández-Muñoz, P.; Catalá, R.; Gavara, R. Antimicrobial packaging of chicken fillets based on the release of carvacrol from chitosan/cyclodextrin films. Int. J. Food Microbiol. 2014, 188, 53-59. [CrossRef]

62. Cheng, M.; Wang, J.; Zhang, R.; Kong, R.; Lu, W.; Wang, X. Characterization and application of the microencapsulated carvacrol/sodium alginate films as food packaging materials. Int. J. Biol. Macromol. 2019, 141, 259-267. [CrossRef] [PubMed]

63. Fang, S.; Zhou, Q.; Hu, Y.; Liu, F.; Mei, J.; Xie, J. Antimicrobial carvacrol incorporated in flaxseed gum-sodium alginate active films to improve the quality attributes of chinese sea bass (Lateolabrax maculatus) during cold storage. Molecules 2019, $24,3292$. [CrossRef] [PubMed] 
64. López-Gómez, A.; Ros-Chumillas, M.; Buendía-Moreno, L.; Martínez-Hernández, G.B. Active cardboard packaging with encapsulated essential oils for enhancing the shelf life of fruit and vegetables. Front. Nutr. 2020, 7, 559978. [CrossRef]

65. López-Gómez, A.; Ros-Chumillas, M.; Buendía-Moreno, L.; Navarro-Segura, L.; Martínez-Hernández, G.B. Active cardboard box with smart internal lining based on encapsulated essential oils for enhancing the shelf life of fresh mandarins. Foods 2020, 9, 590. [CrossRef]

66. Uekama, K.; Hirayama, F.; Irie, T. Cyclodextrin drug carrier systems. Chem. Rev. 1998, 98, 2045-2076. [CrossRef] [PubMed]

67. Ikeda, S.; Uchida, T.; Ichikawa, T.; Watanabe, T.; Uekaji, Y.; Nakata, D.; Terao, K.; Yano, T. Complexation of tocotrienol with $\gamma$-cyclodextrin enhances intestinal absorption of tocotrienol in rats. Biosci. Biotechnol. Biochem. 2010, 74, 1452-1457. [CrossRef] [PubMed]

68. Kashima, N.; Fujikura, Y.; Komura, T.; Fujiwara, S.; Sakamoto, M.; Terao, K.; Nishikawa, Y. Development of a method for oral administration of hydrophobic substances to Caenorhabditis elegans: Pro-longevity effects of oral supplementation with lipid-soluble antioxidants. Biogerontology 2012, 13, 337-344. [CrossRef] [PubMed]

69. Schloesser, A.; Esatbeyoglu, T.; Piegholdt, S.; Dose, J.; Ikuta, N.; Okamoto, H.; Ishida, Y.; Terao, K.; Matsugo, S.; Rimbach, G.; et al. Dietary tocotrienol $/ \gamma$-cyclodextrin complex increases mitochondrial membrane potential and ATP concentrations in the brains of aged mice. Oxidative Med. Cell. Longev. 2015, 2015, 789710. [CrossRef] [PubMed]

70. Žaloudková, L.; Tichá, A.; Nekvindová, J.; Pavlíková, L.; Zadák, Z.; Živný, P. Different forms of ursolic acid and their effect on liver regeneration. Evid. Based Complement. Altern. Med. 2020, 2020, 1-7. [CrossRef]

71. Wüpper, S.; Fischer, A.; Lüersen, K.; Lucius, R.; Okamoto, H.; Ishida, Y.; Terao, K.; Rimbach, G. High dietary kuding tea extract supplementation induces hepatic xenobiotic-metabolizing enzymes-A 6-week feeding study in mice. Nutrients 2019, 12, 40. [CrossRef]

72. Rimbach, G.; Fischer, A.; Schloesser, A.; Jerz, G.; Ikuta, N.; Ishida, Y.; Matsuzawa, R.; Matsugo, S.; Huebbe, P.; Terao, K.; et al. Anti-inflammatory properties of brazilian green propolis encapsulated in a $\gamma$-cyclodextrin complex in mice fed a western-type diet. Int. J. Mol. Sci. 2017, 18, 1141. [CrossRef]

73. Wadhwa, R.; Nigam, N.; Bhargava, P.; Dhanjal, J.K.; Goyal, S.; Grover, A.; Sundar, D.; Ishida, Y.; Terao, K.; Kaul, S.C.; et al. Molecular characterization and enhancement of anticancer activity of caffeic acid phenethyl ester by $\gamma$ cyclodextrin. J. Cancer 2016, 7, 1755-1771. [CrossRef]

74. Bhargava, P.; Grover, A.; Nigam, N.; Kaul, A.; Doi, M.; Ishida, Y.; Kakuta, H.; Kaul, S.C.; Terao, K.; Wadhwa, R.; et al. Anticancer activity of the supercritical extract of Brazilian green propolis and its active component, artepillin C: Bioinformatics and experimental analyses of its mechanisms of action. Int. J. Oncol. 2018, 52, 925-932. [CrossRef] [PubMed]

75. Cho, Y.; Gutierrez, L.; Bordonaro, M.; Russo, D.; Anzelmi, F.; Hooven, J.T.; Cerra, C.; Lazarova, D.L. Effects of propolis and gamma-cyclodextrin on intestinal neoplasia in normal weight and obese mice. Cancer Med. 2016, 5, 2448-2458. [CrossRef] [PubMed]

76. Purpura, M.; Lowery, R.P.; Wilson, J.M.; Mannan, H.; Münch, G.; Razmovski-Naumovski, V. Analysis of different innovative formulations of curcumin for improved relative oral bioavailability in human subjects. Eur. J. Nutr. 2018, 57, 929-938. [CrossRef]

77. Gai, L.; Cai, N.; Wang, L.; Xu, X.; Kong, X. Ursolic acid induces apoptosis via Akt/NF-kB signaling suppression in T24 human bladder cancer cells. Mol. Med. Rep. 2013, 7, 1673-1677. [CrossRef] [PubMed]

78. Wang, J.; Liu, L.; Qiu, H.; Zhang, X.; Guo, W.; Chen, W.; Tian, Y.; Fu, L.; Shi, D.; Cheng, J.; et al. Ursolic acid simultaneously targets multiple signaling pathways to suppress proliferation and induce apoptosis in colon cancer cells. PLoS ONE 2013, 8, e63872. [CrossRef] [PubMed]

79. Jinhua, W. Ursolic acid: Pharmacokinetics processin vitroand In Vivo, a mini review. Arch. Pharm. 2019, 352, e1800222. [CrossRef] [PubMed]

80. Ren, Y.; Liu, Y.; Yang, Z.; Niu, R.; Gao, K.; Yang, B.; Liao, X.; Zhang, J. Solid inclusion complexes of oleanolic acid with aminoappended $\beta$-cyclodextrins (ACDs): Preparation, characterization, water solubility and anticancer activity. Mater. Sci. Eng. C 2016, 69, 68-76. [CrossRef] [PubMed]

81. Esatbeyoglu, T.; Huebbe, P.; Ernst, I.M.A.; Chin, D.; Wagner, A.E.; Rimbach, G. Curcumin-from molecule to biological function. Angew. Chem. Int. Ed. 2012, 51, 5308-5332. [CrossRef] [PubMed]

82. Münch, G.; Venigalla, M.; Gyengesi, E. Curcumin and apigenin-novel and promising therapeutics against chronic neuroinflammation in Alzheimer's disease. Neural Regen. Res. 2015, 10, 1181-1185. [CrossRef]

83. Wupper, S.; Fischer, A.; Luersen, K.; Ipharraguerre, I.R.; Chikamoto, K.; Furune, T.; Ishida, Y.; Terao, K.; Rimbach, G. Effects of dietary gamma-cyclodextrin on voluntary activity and muscle strength in mice. J. Physiol. Pharmacol. 2020, 71. [CrossRef]

84. Singhal, A.; Krystofiak, E.S.; Jerome, W.G.; Song, B. 2-Hydroxypropyl-gamma-cyclodextrin overcomes NPC1 deficiency by enhancing lysosome-ER association and autophagy. Sci. Rep. 2020, 10, 1-14. [CrossRef]

85. Singhal, A.; Szente, L.; Hildreth, J.E.K.; Song, B. Hydroxypropyl-beta and -gamma cyclodextrins rescue cholesterol accumulation in Niemann-Pick C1 mutant cell via lysosome-associated membrane protein. Cell Death Dis. 2018, 9, 1-13. [CrossRef]

86. Davidson, C.D.; Fishman, Y.I.; Puskás, I.; Szemán, J.; Sohajda, T.; McCauliff, L.A.; Sikora, J.; Storch, J.; Vanier, M.T.; Szente, L.; et al. Efficacy and ototoxicity of different cyclodextrins in Niemann-Pick C disease. Ann. Clin. Transl. Neurol. 2016, 3, 366-380. [CrossRef] 
87. Soga, M.; Ishitsuka, Y.; Hamasaki, M.; Yoneda, K.; Furuya, H.; Matsuo, M.; Ihn, H.; Fusaki, N.; Nakamura, K.; Nakagata, N.; et al. HPGCD outperforms HPBCD as a potential treatment for niemann-pick disease type C during disease modeling with iPS cells. Stem Cells 2015, 33, 1075-1088. [CrossRef] [PubMed]

88. Hoque, S.; Kondo, Y.; Sakata, N.; Yamada, Y.; Fukaura, M.; Higashi, T.; Motoyama, K.; Arima, H.; Higaki, K.; Hayashi, A.; et al. Differential effects of 2-hydroxypropyl-cyclodextrins on lipid accumulation in Npc1-Null cells. Int. J. Mol. Sci. 2020, $21,898$. [CrossRef] [PubMed]

89. Schultz, M.L.; Krus, K.L.; Lieberman, A.P. Lysosome and endoplasmic reticulum quality control pathways in niemann-pick type C disease. Brain Res. 2016, 1649, 181-188. [CrossRef] [PubMed]

90. Rosenbaum, A.I.; Maxfield, F.R. Niemann-pick type C disease: Molecular mechanisms and potential therapeutic approaches. J. Neurochem. 2011, 116, 789-795. [CrossRef]

91. Szente, L.; Singhal, A.; Domokos, A.; Song, B. Cyclodextrins: Assessing the impact of cavity size, occupancy, and substitutions on cytotoxicity and cholesterol homeostasis. Molecules 2018, 23, 1228. [CrossRef]

92. Parvez, M.K.; Rishi, V. Herb-drug interactions and hepatotoxicity. Curr. Drug Metab. 2019, 20, 275-282. [CrossRef]

93. Scorletti, E.; Bhatia, L.; McCormick, K.G.; Clough, G.F.; Nash, K.; Hodson, L.; Moyses, H.E.; Calder, P.C.; Byrne, C.D. On behalf of the Welcome study investigators effects of purified Eicosapentaenoic and Docosahexaenoic acids in nonalcoholic fatty liver disease: Results from the Welcome * study. Hepatology 2014, 60, 1211-1221. [CrossRef] [PubMed]

94. Cifuentes, L. Allergy to honeybee not only stings. Curr. Opin. Allergy Clin. Immunol. 2015, 15, 364-368. [CrossRef]

95. Nissim, I.; Niv, M.Y.; Dagan-Wiener, A. The taste of toxicity: A quantitative analysis of bitter and toxic molecules. IUBMB Life 2017, 69, 938-946. [CrossRef] [PubMed] 